\title{
Halogen cycling and aerosol pH in the Hawaiian marine boundary layer
}

\author{
A. A. P. Pszenny ${ }^{1,{ }^{*}}$, J. Moldanová, ${ }^{2,3}$, W. C. Keene $^{4}$, R. Sander ${ }^{2}$, J. R. Maben ${ }^{4}$, M. Martinez ${ }^{5}$, P. J. Crutzen ${ }^{2,6}$, \\ D. Perner ${ }^{2}$, and R. G. Prinn ${ }^{1}$ \\ ${ }^{1}$ Center for Global Change Science, Massachusetts Institute of Technology, Cambridge, MA, USA \\ ${ }^{2}$ Air Chemistry Division, Max Planck Institute for Chemistry, Mainz, Germany \\ ${ }^{3}$ Swedish Environmental Research Institute, Göteborg, Sweden \\ ${ }^{4}$ Department of Environmental Sciences, University of Virginia, Charlottesville, VA, USA \\ ${ }^{5}$ Department of Meteorology, Pennsylvania State University, University Park, PA, USA; now at 2 (above) \\ ${ }^{6}$ Scripps Institution of Oceanography, University of California at San Diego, La Jolla, CA, USA \\ *Now at: Institute for the Study of Earth, Oceans and Space, University of New Hampshire, Durham, and Mount Washington \\ Observatory, North Conway, NH, USA
}

Received: 23 July 2003 - Published in Atmos. Chem. Phys. Discuss.: 5 September 2003

Revised: 16 January 2004 - Accepted: 21 January 2004 - Published: 3 February 2004

\begin{abstract}
Halogen species $\left(\mathrm{HCl}^{*}\right.$ (primarily $\mathrm{HCl}$ ), $\mathrm{Cl}^{*}$ (including $\mathrm{Cl}_{2}$ and $\mathrm{HOCl}$ ), $\mathrm{BrO}$, total gaseous inorganic $\mathrm{Br}$ and size-resolved particulate $\mathrm{Cl}^{-}$and $\mathrm{Br}^{-}$) and related chemical and physical parameters were measured in surface air at Oahu, Hawaii during September 1999. Aerosol pH as a function of particle size was inferred from phase partitioning and thermodynamic properties of $\mathrm{HCl}$. Mixing ratios of halogen compounds and aerosol $\mathrm{pHs}$ were simulated with a new version of the photochemical box model MOCCA that considers multiple aerosol size bins.

Inferred aerosol pHs ranged from 4.5 to 5.4 (median 5.1, $\mathrm{n}=22$ ) for super- $\mu \mathrm{m}$ (primarily sea-salt) size fractions and 2.6 to 5.3 (median 4.6) for sub- $\mu \mathrm{m}$ (primarily sulphate) fractions. Inferred daytime pHs tended to be slightly lower than those at night, although daytime median values did not differ statistically from nighttime medians. Simulated $\mathrm{pHs}$ for most sea-salt size bins were within the range of inferred values. However, simulated $\mathrm{pHs}$ for the largest size fraction in the model were somewhat higher (oscillating around 5.9) due to the rapid turnover rates and relatively larger infusions of sea-salt alkalinity associated with fresh aerosols.
\end{abstract}

Measured mixing ratios of $\mathrm{HCl}^{*}$ ranged from $<30$ to $250 \mathrm{pmol} \mathrm{mol}^{-1}$ and those for $\mathrm{Cl}^{*}$ from $<6$ to $38 \mathrm{pmol} \mathrm{mol}^{-1}$. Simulated $\mathrm{HCl}$ and $\mathrm{Cl}^{*}$ $\left(\mathrm{Cl}+\mathrm{ClO}+\mathrm{HOCl}+\mathrm{Cl}_{2}\right)$ mixing ratios ranged between 20 and $70 \mathrm{pmol} \mathrm{mol}^{-1}$ and 0.5 and $6 \mathrm{pmol} \mathrm{mol}^{-1}$, respectively. Afternoon $\mathrm{HCl}^{*}$ maxima occurred on some days but consistent diel cycles for $\mathrm{HCl}^{*}$ and $\mathrm{Cl}^{*}$ were not observed. Simulated $\mathrm{HCl}$ did vary diurnally, peaking before dusk and reaching a minimum at dawn. While individual

Correspondence to: A. A. P. Pszenny

(alex.pszenny@unh.edu) components of $\mathrm{Cl}^{*}$ varied diurnally in the simulations, their sum did not, consistent with the lack of a diel cycle in observed $\mathrm{Cl}^{*}$.

Mixing ratios of total gaseous inorganic $\mathrm{Br}$ varied from $<1.5$ to $9 \mathrm{pmol} \mathrm{mol}^{-1}$ and particulate $\mathrm{Br}^{-}$deficits varied from 1 to $6 \mathrm{pmol} \mathrm{mol}^{-1}$ with values for both tending to be greater during daytime. Simulated $\mathrm{Br}_{t}$ and $\mathrm{Br}^{-}$mixing ratios and enrichment factors (EFBr) were similar to those observed, with early morning maxima and dusk minima. However, the diel cycles differed in detail among the various simulations. In low-salt simulations, halogen cycling was less intense, $\mathrm{Br}^{-}$accumulated and $\mathrm{Br}_{\mathrm{t}}$ and $\mathrm{EFBr}$ increased slowly overnight. In higher-salt simulations with more intense halogen cycling, $\mathrm{Br}^{-}$and $\mathrm{EFBr}$ decreased and $\mathrm{Br}_{t}$ increased rapidly after dusk. Cloud processing, which is not considered in this version of MOCCA, may also affect these diel cycles (von Glasow et al., 2003). Measured BrO was never above detection limit $\left(\approx 2 \mathrm{pmol} \mathrm{mol}^{-1}\right)$ during the experiment, however relative changes in the $\mathrm{BrO}$ signal during the 3-hour period ending at 11:00 local time were mostly negative, averaging $-0.3 \mathrm{pmol} \mathrm{mol}^{-1}$. Both of these results are consistent with MOCCA simulations of $\mathrm{BrO}$ mixing ratios.

Increasing the sea-salt mixing ratio in MOCCA by $\approx 25 \%$ (within observed range) led to a decrease in $\mathrm{O}_{3}$ of $\approx 16 \%$. The chemistry leading to this decrease is complex and is tied to $\mathrm{NO}_{\mathrm{x}}$ removal by heterogeneous reactions of $\mathrm{BrNO}_{3}$ and $\mathrm{ClNO}_{3}$. The sink of $\mathrm{O}_{3}$ due to the catalytic $\mathrm{Cl}-\mathrm{ClO}$ and $\mathrm{Br}-\mathrm{BrO}$ cycles was estimated at -1.0 to $-1.5 \mathrm{nmol} \mathrm{mol}^{-1}$ day $^{-1}$, a range similar to that due to $\mathrm{O}_{3}$ photolysis in the MOCCA simulations. 


\section{Introduction}

Chemical reactions involving halogen radicals significantly influence the composition of the Earth's atmosphere. These reactions were first discussed in connection with stratospheric ozone loss, especially within the polar vortices during spring (e.g. Wennberg et al., 1994). The photochemical activation of tropospheric $\mathrm{Cl}$ and $\mathrm{Br}$ during polar sunrise episodically enhances oxidation of hydrocarbons (e.g. Jobson et al., 1994) and destruction of $\mathrm{O}_{3}$ (Martinez et al., 1999 and references therein) in near-surface marine air. High concentrations of $\mathrm{BrO}$ and associated $\mathrm{O}_{3}$ destruction have also been observed over salt flats near the Dead Sea and elsewhere (Hebestreit et al., 1999). In contrast, reactions of $\mathrm{Cl}$ atoms with hydrocarbons can enhance $\mathrm{O}_{3}$ production in polluted urban air (Tanaka et al., 2000). Photolysis of I-containing organic compounds emitted by macroalgae in coastal regions initiates I-radical chemistry that may substantially increase production of new particles (O'Dowd et al., 2002).

Although significant and detectable with current technologies, the above influences of halogen radicals in the troposphere are limited in duration and/or spatial extent. However, the marine boundary layer (MBL) covers two thirds of the Earth's surface and contains the highest concentrations of sea-salt and many gaseous halogens in the atmosphere (e.g. Cicerone, 1981; Graedel and Keene, 1995). Although the global impact of halogen radical chemistry in terms of $\mathrm{O}_{3}$ destruction (Dickerson et al., 1999; Galbally et al., 2000), S(IV) oxidation (Vogt et al., 1996; Keene et al., 1998), and related effects in the open-ocean MBL may be greater, they are considerably more difficult to identify there because of less intensive radical chemistry.

Most $\mathrm{Cl}$ and $\mathrm{Br}$ in the MBL originates from sea-salt aerosols produced by wind stress at the ocean surface (e.g. Gong et al., 1997). Fresh sea-salt aerosols rapidly dehydrate towards equilibrium with ambient water vapor and undergo other processes involving the scavenging of reactive gases, aqueous-phase transformations and volatilisation of products. Many of these other processes are strongly $\mathrm{pH}-$ dependent (Keene et al., 1998). In most MBL regions, seasalt alkalinity is rapidly titrated (seconds to minutes) by ambient acids (Chameides and Stelson, 1992; Erickson et al., 1999) and, under a given set of conditions, the pHs of the super- $\mu \mathrm{m}$, sea-salt size fractions approach similar values that are determined by $\mathrm{HCl}$ phase partitioning (Keene and Savoie, 1998, 1999; Keene et al., 2002). Most measurements of particulate $\mathrm{Br}$ in marine air reveal substantial depletions relative to conservative sea-salt tracers (e.g. Sander et al., 2003). Because $\mathrm{HBr}$ is highly soluble in acidic solution, these depletions cannot be explained by acid-displacement reactions (e.g. Ayers et al., 1999). The observed depletions are generally consistent with the predicted volatilisation of $\mathrm{Br}_{2}$ and $\mathrm{BrCl}$ based on autocatalytic halogen activation mechanisms (Vogt et al., 1996):

$\mathrm{HOBr}+\mathrm{Br}^{-}+\mathrm{H}^{+} \rightarrow \mathrm{Br}_{2}+\mathrm{H}_{2} \mathrm{O}$
$\mathrm{HOCl}+\mathrm{Br}^{-}+\mathrm{H}^{+} \rightarrow \mathrm{BrCl}+\mathrm{H}_{2} \mathrm{O}$.

$\mathrm{Br}_{2}$ and $\mathrm{BrCl}$ then photolyse in sunlight to produce atomic $\mathrm{Br}$ and $\mathrm{Cl}$. Most $\mathrm{Br}$ atoms recycle in the gas phase via the reaction sequence:

$\mathrm{Br}+\mathrm{O}_{3} \rightarrow \mathrm{BrO}+\mathrm{O}_{2}$

$\mathrm{BrO}+\mathrm{HO}_{2} \rightarrow \mathrm{HOBr}+\mathrm{O}_{2}$

$\mathrm{HOBr}+\mathrm{h} \nu \rightarrow \mathrm{OH}+\mathrm{Br}$

and thereby catalytically destroy $\mathrm{O}_{3}$, analogous to $\mathrm{Br}$ cycling in the stratosphere (e.g. Mozurkewich, 1995; Sander and Crutzen, 1996). In contrast, most atomic $\mathrm{Cl}$ in the MBL reacts with hydrocarbons via hydrogen extraction to form $\mathrm{HCl}$ vapor, which is relatively stable against chemical degradation. Consequently, $\mathrm{HCl}$ must recycle via a multiphase pathway to sustain significant Cl-radical chemistry without completely dechlorinating sea-salt aerosol (Keene et al., 1990; Graedel and Keene, 1995).

Observational evidence in support of the above scenario in the background MBL is limited in extent and in some cases controversial. Direct measurements of $\mathrm{BrO}$ by differential optical absorption spectroscopy (DOAS) in coastal air (Hönninger, 1999) and over the open ocean (Leser et al., 2003) indicate mixing ratios that are near or below analytical detection limits of about 1 to $3 \mathrm{pmol} \mathrm{mol}^{-1}$ but within the range of model predictions. Although column-integrated DOAS observations from space reveal higher mixing ratios of tropospheric BrO (e.g. Wagner and Platt, 1998), the relative amounts in the MBL cannot be resolved. Strong diel anticorrelations between total volatile inorganic $\mathrm{Br}$ and particulate Br have been reported (e.g. Rancher and Kritz, 1980) but the lack of speciation precludes unambiguous interpretation.

Other measurements suggest that, under some conditions, $\mathrm{Cl}$-atom precursors are produced and accumulate to significant mixing ratios (greater than $100 \mathrm{pmol} \mathrm{mol}^{-1} \mathrm{Cl}$ ) in the dark (Pszenny et al., 1993; Spicer et al., 1998). Photolysis of these precursors following sunrise would sustain significant concentrations of atomic $\mathrm{Cl}\left(>10^{4} \mathrm{~cm}^{-3}\right)$ during the early morning. Chlorine atom concentrations of this order have been inferred from relative concentration changes in hydrocarbons measured during some field campaigns (Singh et al., 1996a; Wingenter et al., 1996). However, model calculations based on the autocatalytic mechanism predict only minor accumulation of $\mathrm{Cl}$-atom precursors at night and low concentrations of atomic $\mathrm{Cl}$ during the day (Keene et al., 1998) relative to those inferred from these measurements (Pszenny et al., 1993; Singh et al., 1996b; Wingenter et al, 1996; Spicer et al., 1998). In addition, other studies based on observed relative concentration changes in hydrocarbons (Parrish et al., 1993; Jobson et al., 1998) and the global $\mathrm{C}_{2} \mathrm{Cl}_{4}$ budget (Singh et al., 1996b) suggest minor to insignificant influences of Cl-radical chemistry in the MBL. It is thus evident that the 
nature of chemical transformations involving inorganic halogens in the MBL and their overall impacts on the composition of the global troposphere are very uncertain.

To help reduce these uncertainties, a multiphase suite of inorganic $\mathrm{Cl}$ and $\mathrm{Br}$ species and related chemical and physical conditions was measured in the relatively clean easterly trade-wind regime over the North Pacific Ocean at Hawaii during September 1999. In this paper, these data are evaluated for consistency with expectations based on the halogen activation mechanism and associated implications for oxidation processes in the remote MBL are assessed.

Although evidence is now mounting that the cycling of reactive iodine compounds may also significantly influence the chemical evolution of MBL air (e.g., McFiggans et al. 2000, and references therein), measurements of aerosol I species were beyond the scope of this effort. Due to this lack of multiphase observational constraints on I cycling the discussion is limited to $\mathrm{Cl}$ and $\mathrm{Br}$ chemistry.

\section{Methods}

\subsection{Site description}

Between 4 and 29 September 1999 (Julian days 248-273), size-resolved marine aerosols and reactive trace gases were sampled at Bellows Air Force Station on the windward coast of Oahu, Hawaii $\left(21^{\circ} 22.0^{\prime} \mathrm{N}, 157^{\circ} 42.8^{\prime} \mathrm{W}\right)$. Unless otherwise noted, air was sampled from the top of a $20-\mathrm{m}$ scaffolding tower on the beachfront and samples were processed in adjacent laboratory containers. Marine air associated with the persistent easterly trades flowed over the site almost continuously for the duration of the experiment. Aerosol sampling was suspended during precipitation events and on rare occasions when winds were along- or offshore. During low tides, waves breaking over shallow reefs approximately $2 \mathrm{~km}$ upwind may have influenced the composition of sampled air relative to that farther offshore. However, no discernable correlations were detected between the measurements and local tidal cycles suggesting that such influences were negligible.

\subsection{Chemical measurements}

Ambient aerosols were sampled during six, one- to three-day intensives covering a total of eleven diel cycles. Twentytwo discrete daytime and nighttime samples (nominal 12hour duration) were collected using a modified (with the addition of a top " 0 " stage) Graseby-Anderson 235 cascade impactor configured with a Liu-Pui type inlet, polycarbonate substrates, and quartz-fiber backup filters (Pallflex 2500 QAT-UP) (e.g. Pszenny et al., 1989; Zhu et al., 1992; Keene et al., 2002). At an average sampling rate of $1.13 \mathrm{~m}^{3} \mathrm{~min}^{-1}$, approximate ambient geometric mean diameters (GMDs) for the sampled size fractions were $21,11,5.2,2.4,1.3,0.65$, and $0.33 \mu \mathrm{m}$. The GMD of the largest fraction was calculated as $\sqrt{2}$ times the theoretical $50 \%$ cut diameter of the stage " 0 " jet plate. The GMD of the smallest fraction was calculated as the theoretical $50 \%$ cut diameter of the next largest stage divided by $\sqrt{2}$. Bulk aerosol was sampled in parallel on quartzfiber filters at an average flow rate of $1.3 \mathrm{~m}^{3} \mathrm{~min}^{-1}$. All air volumes reported were normalised to standard temperature and pressure $\left(0^{\circ} \mathrm{C}, 1 \mathrm{~atm}\right)$. Impactors and bulk-filter cassettes were cleaned, dried, loaded, and unloaded in a Class 100 clean bench. Exposed substrates and filters were transferred to polypropylene tubes, stored in glass jars to minimise gas exchange, frozen, and transported to the University of Virginia (UVA) for chemical analysis. Dynamic field blanks were mounted, exposed by drawing ambient air for one minute, and subsequently processed and analysed using the same procedures as those for samples.

At UVA, half sections of substrates were extracted under sonication in $10 \mathrm{~mL}$ of $>18 \mathrm{M} \Omega \mathrm{cm}^{-1}$ deionized water (DIW) and entire exposed backup and bulk filters were extracted in $40 \mathrm{~mL}$ DIW. Extracts were analysed for $\mathrm{Mg}^{2+}$, $\mathrm{Ca}^{2+}, \mathrm{Na}^{+}$and $\mathrm{K}^{+}$by atomic absorption spectrophotometry, $\mathrm{NH}_{4}^{+}$by automated colorimetry, and $\mathrm{NO}_{3}^{-}, \mathrm{Cl}^{-}, \mathrm{Br}^{-}, \mathrm{SO}_{4}^{2-}$, $\mathrm{CH}_{3} \mathrm{SO}_{3}^{-}$, and $\mathrm{C}_{2} \mathrm{O}_{4}^{2-}$ by high-performance ion chromatography (IC) (Keene and Savoie, 1998; Keene et al., 2002). Data for samples were corrected based on averages for the field blanks. Overall measurement precisions and detection limits (DLs) for particulate species (and for volatile $\mathrm{Cl}$ and total gaseous inorganic $\mathrm{Br}$, see below) were estimated following Keene et al. (1989). Precision for $\mathrm{Br}^{-}, \mathrm{CH}_{3} \mathrm{SO}_{3}^{-}$, and $\mathrm{C}_{2} \mathrm{O}_{4}^{2-}$ averaged $\pm 15 \%$ to $\pm 20 \%$; precision for other analytes averaged about $\pm 10 \%$. Sea-salt and non-sea-salt (nss) constituents were differentiated using $\mathrm{Mg}^{2+}$ as the reference species (Keene et al., 1986). $\mathrm{Mg}^{2+}$ rather than $\mathrm{Na}^{+}$was employed because its background in the quartz-fiber sampling media was relatively lower (compared to sea-salt ratios) and less variable than that for $\mathrm{Na}^{+}$and thereby provided more precise results for filter samples (the $<0.65 \mu \mathrm{m}$ GMD size fraction and bulk aerosol).

Internal losses of super- $\mu \mathrm{m}$ aerosols within Sierra-type cascade impactors average about $25 \%$ to $30 \%$; other sources of bias for size-resolved particulate analytes based on these procedures are generally unimportant (Keene et al., 1990; and references therein). Conjugate anions and cations of gases with $\mathrm{pH}$-dependent solubility such as $\mathrm{HCl}$ and $\mathrm{NH}_{3}$ are generally not conservative when populations of chemically distinct aerosols (e.g. super- $\mu \mathrm{m}$ sea salt and sub- $\mu \mathrm{m} \mathrm{S}$ ) are sampled in bulk (e.g. Keene et al., 1990). Consequently, measurements of these species in bulk samples are potentially unreliable and not considered herein. However, concentrations of most particulate analytes (including $\mathrm{Br}^{-}$and nss $\mathrm{SO}_{4}^{2-}$ ) are conservative in bulk samples. Relative to the corresponding sums over all size fractions, concentrations in bulk samples are both more precise and not subject to bias from internal losses within impactors. Consequently, data for conservative species in bulk samples offer greater resolution for some assessments reported below. 
Volatile inorganic $\mathrm{Cl}$ gases were measured in parallel using the tandem mist chamber technique (Keene et al., 1993; Maben et al., 1995; Keene and Savoie, 1998). Air was sampled over 121 discrete 2-hour intervals at a nominal rate of $16 \mathrm{~L} \mathrm{~min}^{-1}$ through a size-segregating inlet that inertially removed super- $\mu$ m-diameter aerosol from the air stream followed by an in-line Teflon filter (Zefluor $2-\mu \mathrm{m}$ pore diameter) that removed sub- $\mu$ m-diameter aerosol. Mist chamber samplers were positioned in tandem downstream of the inlet. The upstream chamber contained acidic solution $(37.5 \mathrm{mM}$ $\mathrm{H}_{2} \mathrm{SO}_{4}$ and $0.042 \mathrm{mM}\left(\mathrm{NH}_{4}\right)_{2} \mathrm{SO}_{4}$ ) to sample $\mathrm{HCl}^{*}$ (primarily $\mathrm{HCl}$ ); the downstream chamber contained alkaline solution $\left(30.0 \mathrm{mM} \mathrm{NaHCO}_{3}\right.$ and $\left.0.408 \mathrm{mM} \mathrm{NaHSO}_{3}\right)$ to sample $\mathrm{Cl}^{*}$ (including $\mathrm{Cl}_{2}$ and $\mathrm{HOCl}$ ). Total inorganic $\mathrm{Cl}\left(\mathrm{Cl}_{\mathrm{t}}\right)$ was sampled in parallel using a similar system configured with tandem mist chambers, both of which contained alkaline solutions. $\mathrm{Cl}_{\mathrm{t}}$ is approximately equal to $\mathrm{HCl}^{*}+\mathrm{Cl}^{*}$ and thereby provides an independent quality constraint on the data. Sample air volumes were measured with mass flow meters; the meters were plumbed in series and compared with a factory-calibrated meter traceable to the National Institute of Standards and Technology (NIST) immediately before and after the field intensive. Field blanks were generated at the beginning and end of each diel intensive by loading and drawing ambient air through mist solutions for $15 \mathrm{sec}-$ onds. Blanks were subsequently processed using the same procedures as those for samples. Chloride in mist solutions was quantified on site (usually within a few hours after sampling) by IC using matrix-matched standard solutions traceable to NIST. Collection efficiencies and specificities for the $\mathrm{Cl}$ gases were reported by Maben et al. (1995). $\mathrm{HCl}^{*}$ was precise to $\pm 20 \%$ or $\pm 15 \mathrm{pmol} \mathrm{mol}^{-1}$, whichever was the greater absolute value. Prior to 20 September, $\mathrm{Cl}^{*}$ and $\mathrm{Cl}_{\mathrm{t}}$ were precise to $\pm 20 \%$ or $\pm 10 \mathrm{pmol} \mathrm{mol}^{-1}$, whichever was greater. Thereafter, modification of the analytical technique improved precision to $\pm 3 \mathrm{pmol} \mathrm{mol}^{-1}$ and $\mathrm{Cl}_{\mathrm{t}}$ to $\pm 15 \%$ or $\pm 5 \mathrm{pmol} \mathrm{mol}^{-1}$, whichever was greater.

Volatile inorganic $\mathrm{Br}\left(\mathrm{Br}_{\mathrm{t}}\right)$ was sampled at a nominal rate of $85 \mathrm{~L} \mathrm{~min}^{-1}$ in parallel with size-segregated and bulk aerosols using a filter pack technique (Rancher and Kritz, 1980; Li et al., 1994). An open-face, three-stage, 47-mm, polycarbonate filter pack housing was loaded with a quartzfiber (Pallflex 2500 QAT-UP) particle filter followed by tandem rayon filters (Schleicher and Schuell, Grade 8S) impregnated with a solution of $10 \% \mathrm{~K}_{2} \mathrm{CO}_{3}$ and $10 \%$ glycerol (e.g. Bardwell et al., 1990). Collection efficiencies by the upstream impregnated filter were indistinguishable from $100 \%$ (i.e. no detectable breakthrough). Sampling rates were measured with a mass flow meter. Filter packs were cleaned, dried, loaded, and unloaded in a class 100 clean bench. Exposed filters were transferred to polypropylene tubes, stored in glass jars, frozen, and transported to UVA for chemical analysis. Field blanks were generated using procedures similar to those for aerosols. Samples were extracted under sonication in $5 \mathrm{~mL}$ DIW and analysed for $\mathrm{Br}^{-}$by IC using matrix-matched standard solutions. The average precision was $\pm 17 \%$ or $\pm 0.7 \mathrm{pmol} \mathrm{mol}^{-1}$, whichever was the greater absolute value.

$\mathrm{BrO}, \mathrm{NO}_{2}$ and $\mathrm{O}_{3}$ were measured continuously with a long-path DOAS (Platt and Perner, 1983; Platt, 1994; Martinez et al., 1999, 2000). DOAS quantifies trace gases based on distinct narrow absorption features in the UV-VIS spectral region. Light from a white light source (Hanovia L5269, $\mathrm{Xe}$ arc) is directed along an open path of several kilometers through the atmosphere by a parabolic mirror (diameter of $0.3 \mathrm{~m}$, focal length of $0.28 \mathrm{~m}$ ), reflected by an array of 30 retroreflectors of $5-\mathrm{cm}$ diameter each and collected back at the source by a second mirror (diameter of $0.5 \mathrm{~m}$, focal length of $1.25 \mathrm{~m}$ ) which focuses the light into a 0.6-mm quartz fiber. The quartz fiber channels the light into a spectrograph. Column densities of trace gases are obtained from the differential optical densities of distinct absorption features and yield integrated concentrations along the light path. For this experiment the receiving mirror was mounted on the roof of a laboratory container at the base of the tower and the retroreflector array was positioned on the roof of a building on a pier approximately $6.5 \mathrm{~km}$ to the southeast. This configuration allowed an unobstructed path at an average height of approximately $7 \mathrm{~m}$ over near-shore coastal ocean.

The spectrograph, designed and built at the Max-PlanckInstitut für Chemie, is based on a holographic grating (American Holographic 455.01, flat field region $240-800 \mathrm{~nm}$, 550 grooves $/ \mathrm{mm}$, focal length $212 \mathrm{~mm}$, dispersion about $7 \mathrm{~nm} / \mathrm{mm}$ ). Recorded spectra covered the wavelength range between 290 and $460 \mathrm{~nm}$, with a spectral resolution of $0.9 \mathrm{~nm}$. The RY-1024 detector from Scientific Instruments, $\mathrm{GmbH}$ (Hamamatsu photodiode array cooled to $-70^{\circ} \mathrm{C}$ ) is mounted on translation tables for selection of the spectral region and in order to correct for the pixel-to-pixel diode variation of the array by the Multi-Channel Scanning Technique (MCST) (Brauers et al., 1995). A complete spectrum was recorded approximately every $10 \mathrm{~min}$.

The trace gas column densities along the light path were derived from their proper absorbances, which are determined from a simultaneous least-squares fit of reference spectra of all trace compounds and of a polynomial to the air spectrum (Stutz and Platt, 1995). The reference spectrum for $\mathrm{NO}_{2}$ was obtained from a quartz cell filled with the gas placed in the light path. Ozone and halogen oxide spectra recorded in the laboratory prior to deployment to the field were wavelength calibrated according to the $\mathrm{NO}_{2}$ spectrum. Ozone was produced in the lab by flowing oxygen through a silent discharge, and $\mathrm{BrO}$ was generated by irradiating mixtures of $\mathrm{Br}_{2}$ and $\mathrm{O}_{3}$ with 254-nm mercury light (Philips TUV $40 \mathrm{~W}$ ).

The differential absorption cross sections required for the calculation of concentrations were obtained by folding the higher-resolution cross sections (Bass et al., 1984; Wahner et al., 1988; Laszlo et al., 1995; Harder et al., 1997) with Hgline spectra as resolved by the instrument (Platt, 1994). The temperature dependencies of the spectra of $\mathrm{O}_{3}$ and $\mathrm{BrO}$ were 
taken into account. The actual value for the $\mathrm{BrO}$ differential absorption cross section at $338 \mathrm{~nm}$ was $6.2 \times 10^{-18} \mathrm{~cm}^{2}$ at $298 \mathrm{~K}$. Application of the MCST diminished the latter value to $6.1 \times 10^{-18} \mathrm{~cm}^{2}$.

The systematic errors derived for the concentrations are caused mainly by lamp structures (the main limitation of detection) and by uncertainties of the absorption coefficients (3-20\%). Statistical errors arise from photon statistics, from detector noise and from random residual instrument structures. Average absolute detection limit for $\mathrm{BrO}$ was about 2 pmol mol ${ }^{-1}$ and that for $\mathrm{O}_{3}$ was about $10 \mathrm{nmol} \mathrm{mol}^{-1}$, depending on visibility.

In a second evaluation of the $\mathrm{BrO}$ detection limit, an air spectrum measured a few hours earlier was fitted to the actual air spectrum together with the reference spectra to minimise systematic errors caused by lamp structures, which change over time. Only changes in mixing ratios can be obtained this way, but the detection limits for changes in $\mathrm{BrO}$, determined by the 2-sigma uncertainty of the fit, are about a factor of two lower than for absolute $\mathrm{BrO}$ mixing ratios, with a median of $1 \mathrm{pmol} \mathrm{mol}^{-1}$.

$\mathrm{IO}, \mathrm{OClO}$ and $\mathrm{HCHO}$ were also measured but never exceeded their respective detection limits of approximately 1.5 , 1.5 and $400 \mathrm{pmol} \mathrm{mol}^{-1}$. $\mathrm{NO}_{2}$ exceeded its detection limit of approximately $60 \mathrm{pmol} \mathrm{mol}^{-1}$ only during brief periods of offshore flow. $\mathrm{NO}_{3}$ data were not acquired because this molecule absorbs in a different spectral region that was not monitored.

\subsection{Meteorological measurements and ancillary data}

Wind direction, wind speed, air temperature, and relative humidity (RH) were measured continuously at the top of the tower with instruments maintained by the University of Hawaii. Ten-minute averages were provided for the first two intensive sampling periods and one-minute averages thereafter (S. Howell, personal communication, 1999). "Clean sector" winds were defined as coming from azimuths between $35^{\circ}$ and $120^{\circ}$ at speeds greater than $1 \mathrm{~m} \mathrm{~s}^{-1}$.

Five-day, three-dimensional back trajectories were calculated at MIT using version 4.0 of the NOAA/ARL HY-SPLIT model (Draxler, 1995) and three-dimensional wind fields from the EDAS (early ETA model Data Analysis System), which includes both analyses and forecasts. Trajectories ending at five altitudes $(0.3,1.5,2.5,5$ and $9 \mathrm{~km})$ above the sampling site at 00:00, 06:00, 12:00 and 18:00 UT (Universal Time) were calculated for each day of an intensive.

\subsection{Thermodynamic calculations}

Equilibrium hydrogen ion activities for individual aerosol size fractions were calculated based on the measured phase partitioning and associated thermodynamic properties of $\mathrm{HCl}$ following the approach of Keene and Savoie (1998). Briefly, the equilibrium

$\mathrm{HCl}_{\mathrm{g}} \stackrel{K_{H}}{\rightleftharpoons}\left\{\mathrm{HCl}_{\mathrm{aq}}\right\} \stackrel{K_{a \mathrm{HCl}}}{\rightleftharpoons}\left\{\mathrm{H}^{+}\right\}+\left\{\mathrm{Cl}^{-}\right\}$

was evaluated based on simultaneous measurements of $\mathrm{HCl}_{\mathrm{g}}$ (assumed equal to $\mathrm{HCl}^{*}$ ) and particulate $\mathrm{Cl}^{-}$concentrations in air, the Henry's Law $\left(K_{H}\right)$ and acid dissociation constants $\left(K_{a \mathrm{HCl}}\right)$ and associated temperature corrections for $\mathrm{HCl}$ (Marsh and McElroy, 1985), liquid water contents (LWCs) for sea-salt dominated size fractions calculated from hygroscopicity models (e.g. Gerber, 1985; Gong et al., 1997), and activity coefficients (Pitzer, 1991). LWCs for the three smallest size fractions were modeled following Keene et al. (2002) based on Tang and Munkelwitz (1994). $\mathrm{HCl}_{\mathrm{g}}$ mixing ratios, RHs, and temperatures used in the calculations were averaged over the corresponding aerosol sampling intervals. Total acidities $\left(\mathrm{H}_{\mathrm{tot}}=\mathrm{H}^{+}+\right.$undissociated acids $)$for individual aerosol size fractions were estimated based on evaluation of the sulphate-bisulphate equilibrium (Keene et al., 2002):

$\left\{\mathrm{H}^{+}\right\} \times\left\{\mathrm{SO}_{4}^{2-}\right\}=\left\{\mathrm{HSO}_{4}^{-}\right\} \times K_{a \mathrm{HSO}_{4}^{-}}$.

\subsection{Photochemical model calculations}

Multiphase chemical processes were simulated using the box Model Of Chemistry Considering Aerosols (MOCCA) (e.g. Sander and Crutzen, 1996; Vogt et al., 1996, Sander et al., 1999). The chemical mechanism considers reactions both in the gas phase and in deliquesced sea-salt and nss sulphate aerosols. Photochemical reaction rates, assuming clear-sky conditions, vary as a function of solar zenith angle. The reaction mechanism includes $\mathrm{Cl}, \mathrm{Br}$, I and $\mathrm{S}$ compounds and reactions in addition to the standard tropospheric $\mathrm{HO}_{\mathrm{x}}, \mathrm{CH}_{4}$ and $\mathrm{NO}_{\mathrm{x}}$ chemistry. Further information about the model is available at http://www.mpch-mainz.mpg.de/ $\sim$ sander/mocca/.

A new version of the model that evaluates chemical processes involving multiple aerosol size fractions was developed for this analysis. The model was initialised with externally mixed populations of unreacted sea-salt aerosols and pre-existing sulphate aerosols. Sea-salt size bins were centered on diameters of $21,11,5.2,2.4,1.3,0.65$ and $0.33 \mu \mathrm{m}$. The initial concentrations of nss $\mathrm{SO}_{4}^{2-}$ were partitioned into seven size bins with diameters of $2.4,1.3,0.65,0.33,0.17$, 0.09 , and $0.05 \mu \mathrm{m}$ (i.e. the smallest measured size fraction was represented by four model bins with diameters of $0.33,0.17,0.09$ and $0.05 \mu \mathrm{m})$. The total particle volume in each size bin was calculated from the equilibrium molality of sea-salt (Tang, 1997) and $\mathrm{NH}_{4} \mathrm{HSO}_{4}$ (Tang and Munkelwitz, 1994) solutions at the measured ambient relative humidity. The densities of the equilibrium solutions were calculated using parameters of Clegg and Whitfeldt (1991) for sea-salt and of Tang and Munkelwitz (1994) for $\mathrm{NH}_{4} \mathrm{HSO}_{4}$. The Kelvin effect was considered for the sub- $\mu \mathrm{m}$ size fractions. The average atmospheric lifetimes of particles in each 
(a)

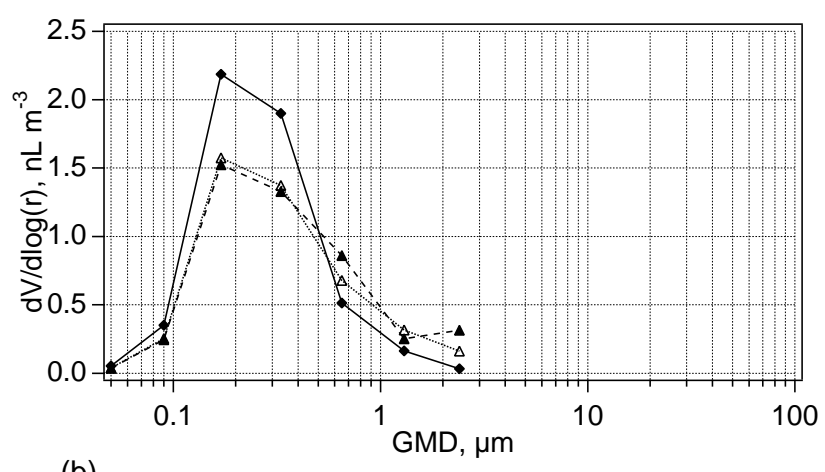

(b)

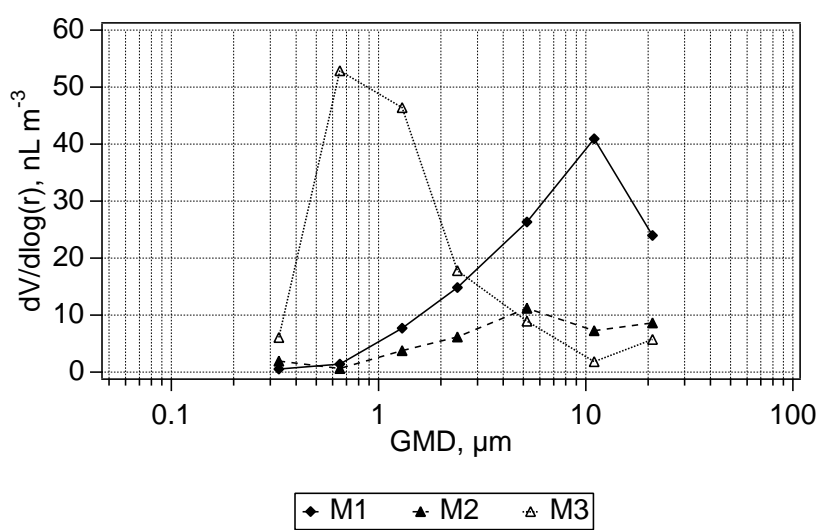

Fig. 1. Volume size distributions of sulphate (a) and sea-salt (b) aerosols used in model simulations. Distributions for simulation M4 were identical to those for simulation M1.

size bin against dry deposition to the sea surface were based on Slinn and Slinn (1980). Emissions of sea-salt particles were equated to their dry-deposition fluxes thereby maintaining constant atmospheric concentrations. At each time step, fresh aerosol was added to, and an equivalent amount of reacted aerosol removed from, each sea-salt size bin in proportion to the corresponding atmospheric lifetime. This procedure sustained finite thermodynamic disequilibria for the internally mixed aerosols in each sea-salt size fraction; the magnitude of disequilibrium increased with particle size. During simulations, nss $\mathrm{SO}_{4}^{2-}$ accumulated in both sea-salt and sulphate aerosols via dissolution and oxidation of $\mathrm{SO}_{2}$ and condensation of $\mathrm{H}_{2} \mathrm{SO}_{4}$.

Initial conditions for model runs are summarised in Table 1 and Fig. 1. Processes were simulated over a range of conditions to investigate multiphase variability in bromine species, differences in chlorine and bromine volatilisation as a function of particle size, and the sensitivity of $\mathrm{O}_{3}$ to halogen chemistry.

\section{Results and discussion}

3.1 Meteorological condition summaries for intensive sampling periods

The meteorological data obtained on the tower and $\mathrm{NO}_{3}^{-}$and nss $\mathrm{SO}_{4}^{2-}$ concentrations measured in cascade impactor samples collected during each intensive are summarised in Table 2. The back-trajectories indicated that large-scale anticyclonic flow of variable strength delivered air to the vicinity of the Hawaiian Islands throughout the experiment. No recent (i.e. within the five days represented by the trajectories) continental influence was suggested by any of the trajectories calculated for the first five intensive periods. During Intensive \#6, however, the trajectories at all except the $9 \mathrm{~km}$ endpoint level indicated relatively vigorous anticyclonic flow. A distinctive feature in this trajectory set was the $5 \mathrm{~km}$ endpoint trajectories from the beginning of the period through 27 September, 00:00 UT, which suggested that air at this end-point altitude had passed close to and perhaps over the northwest U.S. - southwest Canadian shoreline at high altitude three to four days before arriving at the site. These $5 \mathrm{~km}$ endpoint trajectories suggested further that prior to about 4 days back, the air at this endpoint level may have been transported rapidly across the mid-latitude North Pacific from Asia. The 27 September, 06:00 UT $5 \mathrm{~km}$ endpoint trajectories and subsequent ones indicated much less rapid, more localised flow. Nitrate and $\mathrm{nss}_{4}^{2-}$ concentrations peaked later in the period (sample collected 27 September, 16:31 UT to 28 September, 04:10 UT). The back trajectories in combination with the relatively high $\mathrm{NO}_{3}^{-}$and $\mathrm{nss} \mathrm{SO}_{4}^{2-}$ concentrations observed during this period strongly suggest that continental pollutants were transported into the vicinity of Hawaii early during (and perhaps prior to) the period and then affected the air sampled near-surface after roughly a one-day delay.

\subsection{Aerosol acidity}

We inferred aerosol $\mathrm{pH}$ by evaluating the thermodynamic equilibrium between gas-phase $\mathrm{HCl}$ and aqueous $\mathrm{Cl}^{-}$. Results are summarised in Table 3 . Several potential sources of error are associated with this method. These include uncertainties in field measurements $\left(\mathrm{HCl}\right.$, particulate $\mathrm{Cl}^{-}, \mathrm{RH}$ and temperature), reliability of the hygroscopic growth models and associated assumptions involved in estimating aerosol LWCs, accuracy of Henry's Law and acid dissociation constants for $\mathrm{HCl}$, and the assumption that the multiphase system is at thermodynamic equilibrium with respect to $\mathrm{HCl}$. Measurement uncertainties are described above and, in most cases, correspond to relatively minor sources of error in inferred acidity ( $< \pm 0.1 \mathrm{pH}$ unit). LWCs estimated using different models (e.g. Gerber, 1985; Tang, 1997 for sea-salt) generally agree within about $\pm 25 \%$ and, consequently, also 
Table 1. (a) Description of aerosol and ozone mixing ratio in MOCCA model simulations.

\begin{tabular}{cccccc}
\hline $\begin{array}{c}\text { Model } \\
\text { simulation }\end{array}$ & $\begin{array}{c}\text { Aerosol volume } \\
\left(\mathrm{nL} \mathrm{m}^{-3}\right)\end{array}$ & \multicolumn{2}{c}{$\begin{array}{c}\text { Volume mean diameter } \\
(\mu \mathrm{m}) / \text { number mean } \\
\text { diameter }(\mu \mathrm{m})\end{array}$} & $\begin{array}{c}\text { Ozone mixing } \\
\text { ratio }\end{array}$ \\
& Sea-salt & Sulphate & Sea-salt & Sulphate & nmol mol $^{-1}$ \\
\hline M1 & 28.6 & 1.4 & $8.98 / 0.59$ & $0.32 / 0.10$ & 20 \\
M2 & 10.1 & 1.2 & $7.45 / 0.37$ & $0.48 / 0.10$ & 20 \\
M3 & 36.0 & 1.2 & $2.10 / 0.50$ & $0.44 / 0.10$ & 20 \\
M4 & 28.6 & 1.4 & $8.98 / 0.59$ & $0.32 / 0.10$ & 30 \\
\hline
\end{tabular}

Table 1. (b) Initial conditions common to all MOCCA simulations.

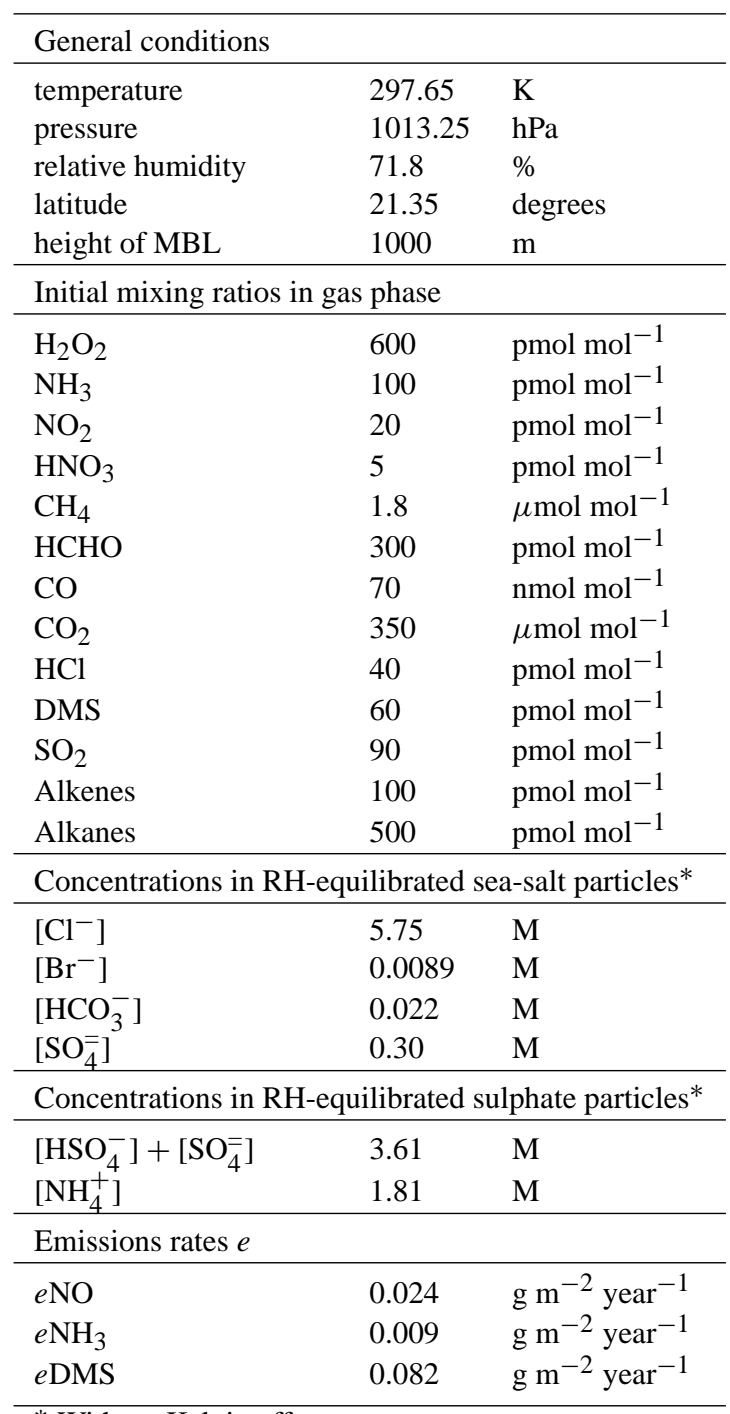

* Without Kelvin effect correspond to relatively minor uncertainties in calculated aerosol acidity ( $< \pm 0.1 \mathrm{pH}$ unit, Keene and Savoie, 1998).

Uncertainty in the Henry's Law constant for $\mathrm{HCl}$ corresponds to a potentially large source of error for this approach (Keene and Savoie, 1999). Published constants for $\mathrm{HCl}$ vary over three orders of magnitude (see Sander, 1999). The value used for the calculations reported herein $\left(1.1 \mathrm{M} \mathrm{atm}^{-1}\right.$, Marsh and McElroy, 1985) is similar to that reported by Brimblecombe and Clegg (1989) but is at the lower limit of published values. If the actual Henry's Law constant for $\mathrm{HCl}$ is greater, aerosol acidities must be proportionately greater to sustain the measured phase partitioning. In this regard, we note that the average acidities of the super- $\mu \mathrm{m}$ sea-salt size fractions inferred from measured $\mathrm{HCl}$ phase partitioning under moderately polluted conditions at Bermuda ( $\mathrm{pH} 3.5$ to 4.5, Keene and Savoie, 1999) were within the range of individual detectable values estimated from direct acidity measurements under comparable conditions at the same location the following year ( $\mathrm{pH} 3.3$ to 5.5 with only two greater than 5.0, Keene et al., 2002). The consistency of these results suggests that the Henry's Law constant adopted herein (and by Keene and Savoie, 1999) is probably close to the true value.

Finally, this approach is based on the evaluation of thermodynamic equilibrium. Although sub- $\mu \mathrm{m}$ aerosols equilibrate rapidly with the gas phase, non-equilibrium conditions for the larger aerosol size fractions (e.g. Meng and Seinfeld, 1996) could introduce bias in calculated acidities. However, kinetic models suggest that most sea-salt alkalinity in most remote marine regions is rapidly titrated and nearequilibrium $\mathrm{pH}$ is established within seconds to tens of minutes after aerosol formation (Chameides and Stelson, 1992; Erickson et al., 1999). Corresponding lifetimes for most seasalt aerosols against dry deposition are many hours to a few days. Although the chemical composition of recently acidified sea-salt continues to evolve toward equilibrium with the gas phase via incorporation of acids and volatilisation of $\mathrm{HCl}$, model calculations indicate that aerosol $\mathrm{pH}$ is regulated by $\mathrm{HCl}$ phase partitioning and, thus, under a given set of conditions, remains relatively constant after the initial alkalinity has been titrated (Keene and Savoie, 1998, 1999; Erickson et al., 1999). In addition, the super- $\mu \mathrm{m}$ aerosol 
Table 2. Summary of meteorological and other ancillary data for each aerosol sample interval. Median values are given for meteorological

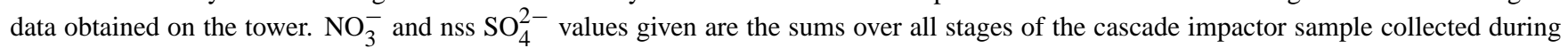
each intensive.

\begin{tabular}{|c|c|c|c|c|c|c|c|c|}
\hline $\begin{array}{c}\text { Start } \\
(\mathrm{UT}, 1999)\end{array}$ & $\begin{array}{c}\text { End } \\
(\mathrm{UT}, 1999)\end{array}$ & $\begin{array}{l}\text { WDir } \\
\left({ }^{\circ} \text { True }\right)\end{array}$ & $\begin{array}{c}\text { WSpd } \\
\left(\mathrm{m} \mathrm{sec}^{-1}\right)\end{array}$ & $\begin{array}{c}\mathrm{T} \\
\left({ }^{\circ} \mathrm{C}\right)\end{array}$ & $\begin{array}{l}\mathrm{RH} \\
(\%)\end{array}$ & $\begin{array}{l}\% \text { in } \\
\text { sector }\end{array}$ & $\begin{array}{c}\mathrm{NO}_{3} \\
\left(\mathrm{nmol} \mathrm{m}^{-3}\right)\end{array}$ & $\begin{array}{c}\mathrm{nss} \mathrm{SO}_{4}^{2-} \\
\left(\mathrm{nmol} \mathrm{m}^{-3}\right)\end{array}$ \\
\hline \multicolumn{9}{|l|}{ Intensive 1} \\
\hline 4 Sep, 04:50 & 4 Sep, 16:18 & 071 & 6.9 & 25.0 & 69.5 & 100. & 4.3 & 4.7 \\
\hline 4 Sep, $16: 30$ & 5 Sep, 05:00 & 070 & 6.6 & 25.3 & 67.2 & 100. & 4.9 & 5.0 \\
\hline \multicolumn{9}{|l|}{ Intensive 2} \\
\hline 7 Sep, 04:55 & 7 Sep, 16:07 & 063 & 4.8 & 25.1 & 74.9 & 100. & 2.0 & 2.3 \\
\hline 7 Sep, 16:19 & 8 Sep, 04:16 & 051 & 6.1 & 25.6 & 68.6 & 100. & 3.5 & 4.5 \\
\hline \multicolumn{9}{|l|}{ Intensive 3} \\
\hline 11 Sep, 04:30 & 11 Sep, $16: 10$ & 089 & 5.4 & 25.1 & 69.7 & 99.9 & 4.1 & 4.1 \\
\hline 11 Sep, $16: 30$ & 12 Sep, 04:10 & 079 & 4.3 & 25.6 & 72.0 & 75.6 & 3.6 & 3.6 \\
\hline $12 \mathrm{Sep}, 04: 30$ & 12 Sep, 16:06 & 070 & 5.5 & 25.1 & 71.1 & 100. & 3.3 & 3.9 \\
\hline 12 Sep, $16: 30$ & $13 \mathrm{Sep}, 04: 00$ & 064 & 5.9 & 25.6 & 68.7 & 100. & 2.5 & 3.1 \\
\hline \multicolumn{9}{|l|}{ Intensive 4} \\
\hline 16 Sep, 04:30 & 16 Sep, 16:09 & 077 & 6.8 & 25.2 & 69.3 & 100. & 3.2 & 4.1 \\
\hline 16 Sep, $16: 36$ & 17 Sep, 04:15 & 077 & 5.9 & 25.6 & 72.2 & 83.6 & 2.6 & 4.2 \\
\hline 17 Sep, 04:25 & 17 Sep, 16:15 & 071 & 6.1 & 25.2 & 72.3 & 100. & 3.0 & 4.5 \\
\hline 17 Sep, $16: 33$ & 18 Sep, 04:10 & 073 & 5.9 & 25.8 & 70.3 & 98.6 & 3.4 & 4.8 \\
\hline \multicolumn{9}{|l|}{ Intensive 5} \\
\hline $20 \mathrm{Sep}, 16: 30$ & 21 Sep, 04:10 & 067 & 5.5 & 25.6 & 68.4 & 100. & 1.5 & 2.6 \\
\hline 21 Sep, 04:33 & 21 Sep, 16:10 & 067 & 5.4 & 24.8 & 71.3 & 97.0 & 1.2 & 2.0 \\
\hline 21 Sep, $16: 32$ & 22 Sep, 04:15 & 073 & 6.5 & 25.5 & 70.0 & 100. & 2.6 & 2.4 \\
\hline 22 Sep, 04:39 & 22 Sep, 16:15 & 075 & 7.2 & 25.1 & 72.8 & 97.8 & 2.5 & 2.9 \\
\hline \multicolumn{9}{|l|}{ Intensive 6} \\
\hline $26 \mathrm{Sep}, 04: 30$ & $26 \mathrm{Sep}, 16: 10$ & 085 & 6.3 & 25.3 & 75.1 & 96.9 & 3.2 & 3.8 \\
\hline 26 Sep, $16: 30$ & 27 Sep, 04:10 & 073 & 5.3 & 25.8 & 74.9 & 100. & 5.4 & 4.4 \\
\hline 27 Sep, 04:36 & 27 Sep, 16:10 & 073 & 5.0 & 25.1 & 75.3 & 100. & 4.7 & 5.0 \\
\hline 27 Sep, 16:31 & $28 \mathrm{Sep}, 04: 10$ & 058 & 4.0 & 25.5 & 66.0 & 93.9. & 9.0 & 6.5 \\
\hline 28 Sep, 05:28 & 28 Sep, $16: 10$ & 082 & 2.2 & 24.3 & 80.8 & 48.1 & 4.1 & 5.5 \\
\hline 28 Sep, $16: 30$ & 29 Sep, 04:10 & 072 & 4.6 & 25.7 & 73.2 & 100. & 3.3 & 4.1 \\
\hline
\end{tabular}

size fractions at Hawaii exhibited small $\mathrm{Cl}^{-}$deficits relative to sea-salt (Table 3) and, consequently, the small $(<20 \%)$ changes in aqueous $\mathrm{Cl}^{-}$concentrations between fresh and fully equilibrated sea-salt would have only minor influences on calculated acidities $(<0.1 \mathrm{pH}$ unit). Based on the above, the $\mathrm{pHs}$ of acidified aerosols estimated using this approach are probably reliable to about \pm 0.2 to $\pm 0.3 \mathrm{pH}$ unit.

The inferred equilibrium $\mathrm{pHs}$ for all aerosol size fractions analysed during the experiment were acidic (Table 3). Calculated $\mathrm{pHs}$ for super- $\mu \mathrm{m}$ fractions ranged from 4.5 to 5.4 with a median value of 5.1. Acidities of $0.65-\mu \mathrm{m}$ size fractions were relatively greater (median $\mathrm{pH}$ of 4.6) and more variable (Table 3). Most $\mathrm{Cl}^{-}$concentrations in the $<0.65 \mu \mathrm{m}$ size fraction were less than the detection limit thereby precluding the application of this approach to estimate corresponding acidities. The greatest aerosol acidities during the experiment were associated with the apparent pollution transport episode on 28 September 1999. Aerosol pHs during that period fell within the upper range of reported values for moderately polluted conditions over the western North Atlantic Ocean (Keene and Savoie, 1999; Keene et al., 2002).
Laskin et al. (2003) recently hypothesized based on laboratory experiments that the reaction $\mathrm{OH}+\mathrm{Cl}^{-} \rightarrow \mathrm{OH}^{-}+\mathrm{Cl}$ at the surfaces of deliquesced sea-salt aerosols slows aerosol acidification and, thus, speeds $\mathrm{S}(\mathrm{IV})$ oxidation by $\mathrm{O}_{3}$ during daytime in clean marine air. Data generated during this experiment were examined for evidence in support of this hypothesis. Median $\mathrm{pH}$ values inferred from $\mathrm{HCl}$ phase partitioning for each of the six largest size fractions did not differ statistically day vs. night (Mann-Whitney U tests, $\alpha=0.05$ ), although the median in each fraction was 0.1 to $0.2 \mathrm{pH}$ unit lower during the day than at night (Fig. 2a). Nss- $\mathrm{SO}_{4}^{2-}$ distributions also differed insignificantly day vs. night (Fig. 2b). Both of these observations are in agreement with MOCCA simulation results (Fig. 3b). $\mathrm{HCl}^{*}$ mixing ratios, with 2-hour time resolution, provide a diagnostic of aerosol acidity during midday. $\mathrm{HCl}$ is infinitely soluble in alkaline solution and its uptake is diffusion limited. Significant production of alkalinity during midday would favor $\mathrm{HCl}$ partitioning into the aerosol and, thus, smaller $\mathrm{HCl}$ mixing ratios in the gas phase. Systematic midday decreases in $\mathrm{HCl}^{*}$ were not evident (Fig. 4). Indeed, during the two cleanest sampling 

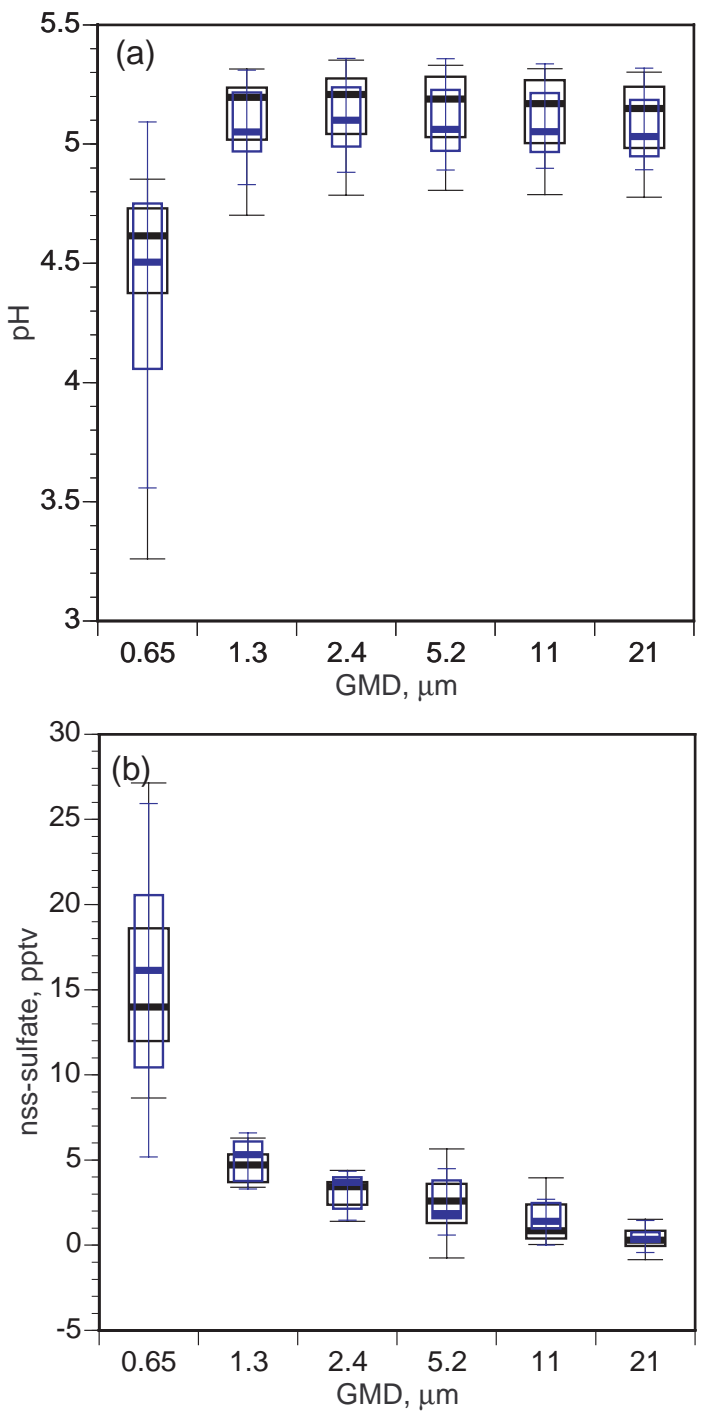

Fig. 2. Box-whisker plots of (a) aerosol pH during daytime (narrow blue boxes) and nighttime (wide black boxes) inferred from $\mathrm{HCl}$ phase partitioning, and (b) measured nss- $\mathrm{SO}_{4}^{2-}$ as a function of particle size. Box tops and bottoms indicate quartile values, whiskers indicate decile values, and thick horizontal bars indicate median values. Eleven daytime and eleven nighttime values were available for constructing each box.

periods (intensives 2 and 5, Table 2), $\mathrm{HCl}^{*}$ mixing ratios peaked during midday (Fig. 4). These results suggest that the Laskin et al. (2003) mechanism of alkalinity production via surface reaction of $\mathrm{OH}$ with $\mathrm{Cl}^{-}$in sea-salt aerosols did not affect $\mathrm{S}$ cycling appreciably under these clean marine conditions.

The $\mathrm{H}^{+}+\mathrm{SO}_{4}^{2-} \rightleftharpoons \mathrm{HSO}_{4}^{-}$equilibrium resulted in most total acidity existing as $\mathrm{HSO}_{4}^{-}$in all aerosol size fractions (Table 3, Saxena et al., 1993; Keene et al., 2002). Based on median values, total acidities were typically about 1.5 orders of magnitude greater than corresponding $\mathrm{H}^{+}$concentrations. In addition, all total acidities (expressed as $-\log _{10}\left[\mathrm{H}_{\text {tot }}^{+}\right]$or
$\mathrm{pH}_{\mathrm{t}}$ ) for the four largest size fractions fell within a narrow range of 2.9 to 3.6 over the variable conditions observed during this experiment (Table 3). It is evident from Eq. (2) that at the high concentrations of $\mathrm{SO}_{4}^{2-}$ and low concentrations of $\mathrm{H}^{+}$that are typical of sea-salt aerosols (e.g. Table 3, Keene et al., 2002), the ratio $\left[\mathrm{HSO}_{4}^{-}\right] /\left[\mathrm{H}^{+}\right]$is large and varies almost linearly with total $\left[\mathrm{SO}_{4}^{2-}\right]$. Thus, the total acidity in sea-salt size fractions is determined in part by the total amount of $\mathrm{SO}_{4}^{2-}$ present. Based on median values for the four largest size fractions, sea-salt accounted for $94 \%$ of total $\mathrm{SO}_{4}^{2-}$ and sea-salt concentrations exhibited relatively little variability over the course of the experiment (Table 3 ). In addition RH varied within a fairly narrow range (Table 2 ) and, thus, water contents per unit sea-salt were similar across the super$\mu \mathrm{m}$ size fractions (e.g. Gerber, 1985). Consequently, total $\left[\mathrm{SO}_{4}^{2-}\right]$ and total acidity exhibited relatively little variability across the four largest size fractions during the course of the experiment. Although $\mathrm{HSO}_{4}^{-}$represents a large fraction of total acidity in sea-salt aerosol solutions at Hawaii, absolute concentrations are low relative to the total amount of acidity in the entire multiphase system; gaseous acids (e.g. $\mathrm{HCl}$ ) and sub- $\mu \mathrm{m}$ aerosol size fractions (Table 3 ) are the dominant reservoirs.

Equations (1) and (2) show that $\mathrm{HCl}$ mixing ratios and the sulphate equilibrium are directly coupled through $\mathrm{H}^{+}$. For instance, combining and reorganising these expressions yields

$$
\frac{\mathrm{HCl}_{\mathrm{g}}}{\left\{\mathrm{HSO}_{4}^{-}\right\}}=\frac{\left\{\mathrm{Cl}^{-}\right\}}{\left\{\mathrm{SO}_{4}^{2-}\right\}} \times \frac{K_{a \mathrm{HSO}_{4}^{-}}}{K_{a \mathrm{HCl}} \times K_{H}} .
$$

In all but the most polluted marine regions, $\mathrm{Cl}^{-}$and $\mathrm{SO}_{4}^{2-}$ in sea-salt size fractions are present at concentrations close to sea-salt ratios and, consequently, the right side of the equation exhibits relatively little variability over the global MBL. Thus, the left side of the equation must also be relatively constant. This relationship provides useful context for comparing aerosol acidities across variable chemical regimes.

Median total acidities (expressed as $\mathrm{pH}_{\mathrm{t}}$ ) for the four largest size fractions at Hawaii (3.3 to 3.4, Table 3) were within the range of those observed in association with higher levels of pollutants at Bermuda (2.7 to 3.5, Keene et al., 2002). In contrast, the corresponding median $\mathrm{H}^{+}$activities (expressed as $\mathrm{pH}$ ) at Hawaii (5.1 for all size fractions, Table 3) were less than those at Bermuda (4.1 to 4.6, Keene et al., 2002). As was the case at Hawaii, sea-salt accounted for most $(93 \%)$ of total $\mathrm{SO}_{4}^{2-}$ in the four largest size fractions at Bermuda and corresponding median concentrations of total $\mathrm{SO}_{4}^{2-}\left(6.9 \mathrm{nmol} \mathrm{m}^{-3}\right.$, Keene et al., 2002) were similar to those at Hawaii $\left(5.3 \mathrm{nmol} \mathrm{m}^{-3}\right)$. However, RHs at Bermuda (median $=91 \%$ for the subset of samples with detectable acidities, Keene et al., 2002) were greater than those at Hawaii (Table 2). Consequently, aqueous concentrations of $\left[\mathrm{SO}_{4}^{2-}\right],\left[\mathrm{HSO}_{4}^{-}\right]$, and corresponding equilibrium ratios of $\left[\mathrm{HSO}_{4}^{-}\right] /\left[\mathrm{H}^{+}\right]$for detectable acidities at Bermuda were also 
a)

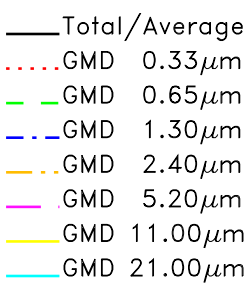

b)

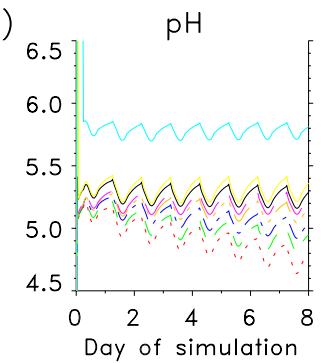

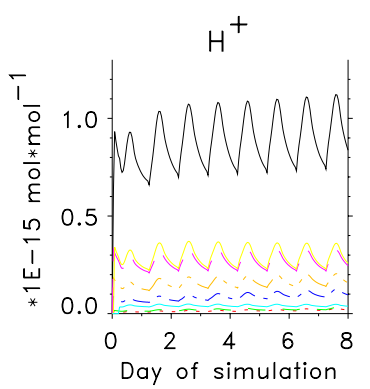
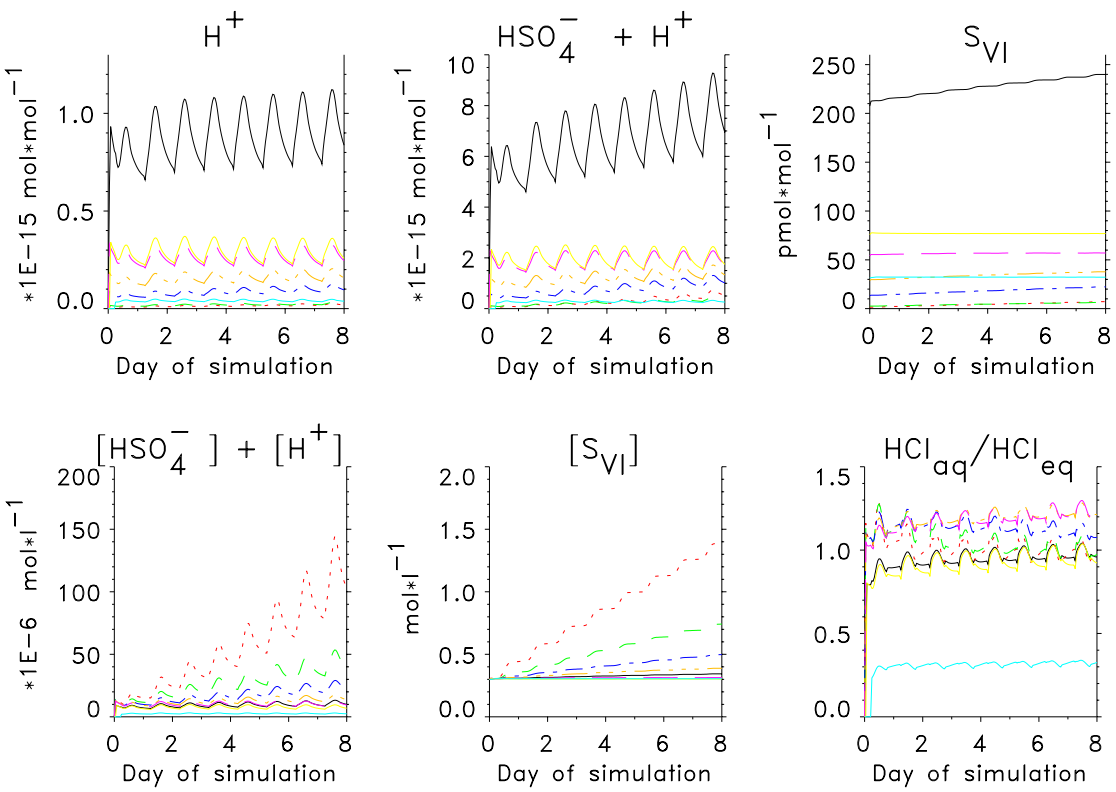

Fig. 3. Mixing ratios (a) and aqueous concentrations (b) in sea-salt aerosol simulated in $\mathrm{M} 1$. For $\mathrm{HCl}$ the ratio $[\mathrm{HCl}]_{\mathrm{aq}} /[\mathrm{HCl}]_{\mathrm{eq}}$ is shown, where the denominator is the equilibrium concentration with gas-phase $\mathrm{HCl}$.

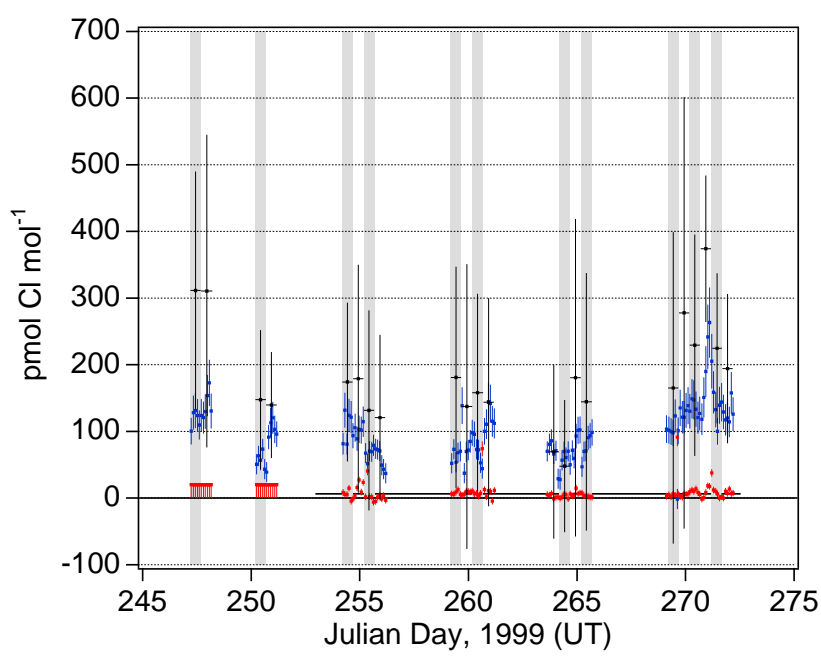

Fig. 4. Measured mixing ratios of $\mathrm{HCl}^{*}$ (blue) and $\mathrm{Cl}^{*}$ (red) and corresponding $\mathrm{Cl}^{-}$deficits (black) summed over the impactor size fractions. All $\mathrm{Cl}^{*}$ values were below a detection limit of about $20 \mathrm{pmol} \mathrm{mol}^{-1}$ during the first two intensive sampling periods. The lower detection limit of approximately $6 \mathrm{pmol} \mathrm{mol}^{-1}$ during the rest of the experiment is indicated by the thin black line drawn from JD 253 to JD 273. Error bars for $\mathrm{HCl}^{*}$ and $\mathrm{Cl}^{*}$ correspond to precisions stated in the text. For $\mathrm{Cl}^{-}$deficits the horizontal error bars correspond to the sampling intervals and the vertical error bars represent the propagated precisions associated with the 14 individual measurements $\left(7 \mathrm{Cl}^{-}\right.$and $\left.7 \mathrm{Mg}^{2+}\right)$ underlying each sum. Shaded vertical bands indicate nighttime (sunset to sunrise) intervals during each intensive sampling period. lower. The influences of higher solution $\left[\mathrm{H}^{+}\right]$and higher aerosol water content on $\left[\mathrm{HSO}_{4}^{-}\right]$at Bermuda relative to Hawaii were of comparable magnitude but opposite direction resulting in similar median total acidities in the four largest size fractions at the two sites. Although not measured at Bermuda during Spring 1997, we would predict from Eq. (3) that the corresponding $\mathrm{HCl}_{\mathrm{g}}$ mixing ratios during that period were within the same range as those at Hawaii (Table 3). $\mathrm{HCl}_{\mathrm{g}}$ mixing ratios under conditions of lower $\mathrm{RH}(79 \%$ to 93\%) at Bermuda during Spring 1996 ranged from 133 to $883 \mathrm{pmol} \mathrm{mol}^{-1}$ (Keene and Savoie, 1998), which overlap the range of values at Hawaii.

Sea-salt aerosol pHs simulated by MOCCA were generally in agreement with those inferred from thermodynamic relationships with simulated values for most size fractions ranging between 4.9 and 5.5 (Fig. 3b). The corresponding range of $\mathrm{pHs}$ of super- $\mu \mathrm{m}$ size fractions inferred from thermodynamic relationships was 4.5 to 5.4 (Table 3). However, $\mathrm{pHs}$ for the largest size fraction in model simulations oscillated around a somewhat higher value of 5.9 due primarily to the rapid turnover rates and relatively larger infusions of alkalinity associated with fresh sea-salt aerosols. The constant production of new aerosols by wave action and the constant removal of reacted aerosols via deposition sustains dynamic disequilibria in both the model and in the ambient MBL. Larger size fractions have short lifetimes against deposition (in the model, 43,18 and $8 \mathrm{~h}$, respectively for particles with diameters 5.2, 11 and $21 \mu \mathrm{m}$ ). The corresponding times required to titrate sea-salt alkalinity and to acidify particles of these sizes to near equilibrium $\mathrm{pHs}$ were approximately $0.5,2$ and $6 \mathrm{~h}$, respectively. For the largest size fraction, the 
Table 3. Summary statistics for size-segregated aerosol composition at Hawaii during summer $(\mathrm{N}=22)$.

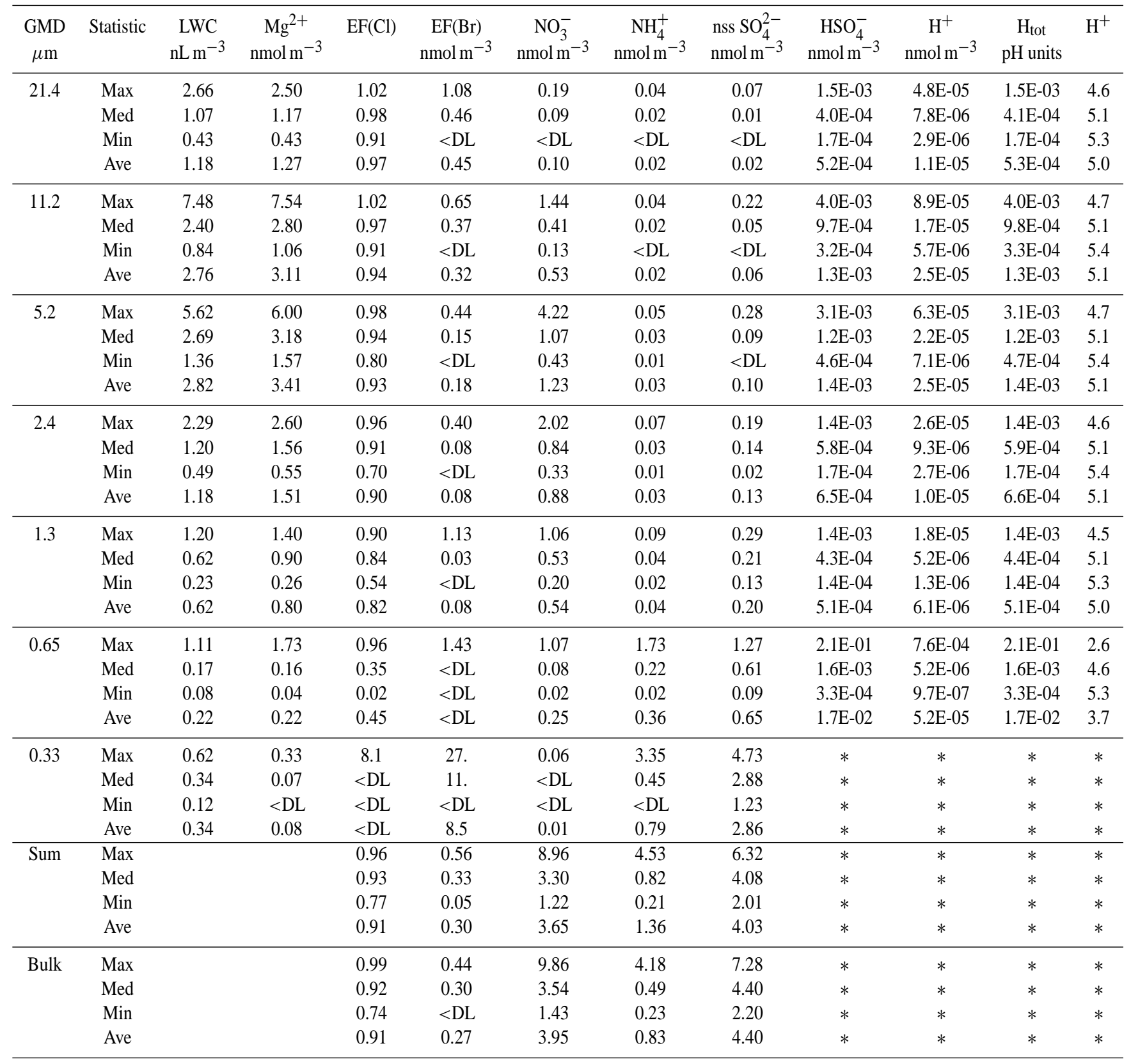

Average $\mathrm{Cl}^{-}$and $\mathrm{Br}^{-}$enrichment factors based on average $\mathrm{Mg}^{2+}$ and average $\mathrm{Cl}^{-}$and $\mathrm{Br}^{-}$, respectively, for all samples.

* Particulate $\mathrm{Cl}^{-}$concentrations below detection limit; acidities and $\mathrm{HSO}_{4}^{-}$cannot be inferred.

turnover rate and the rate of alkalinity titration are of similar magnitude and, consequently, the thermodynamic approach overestimates acidities of the largest particles.

The last panel in Fig. 3 depicts the equilibrium state of the modeled sea-salt particles with respect to $\mathrm{HCl}$. From Eq. (1) the $y$-axis equals $\left\{\mathrm{H}^{+}\right\} \times\left\{\mathrm{Cl}^{-}\right\} /\left(\left\{\mathrm{H}^{+}\right\} \times\left\{\mathrm{Cl}^{-}\right\}\right)_{\text {eq }}$. Because $\left\{\mathrm{Cl}^{-}\right\}$is many orders of magnitude larger than $\left\{\mathrm{H}^{+}\right\}$,
$\left\{\mathrm{Cl}^{-}\right\} /\left\{\mathrm{Cl}^{-}\right\}_{\text {eq }} \approx 1$ for the equilibrium in question and the ratio on the $y$-axis reflects variations in $\left\{\mathrm{H}^{+}\right\} /\left\{\mathrm{H}^{+}\right\}_{\text {eq }}$. The panel shows that $\left\{\mathrm{H}^{+}\right\}$in the largest size fraction was 35 times lower $(0.5-0.7 \mathrm{pH}$ unit) than the equilibrium value with respect to $\mathrm{HCl}$. The size fractions with diameter $5.2 \mu \mathrm{m}$ and smaller became slightly supersaturated and released $\mathrm{HCl}$ to the gas phase. Initially the supersaturation was larger 

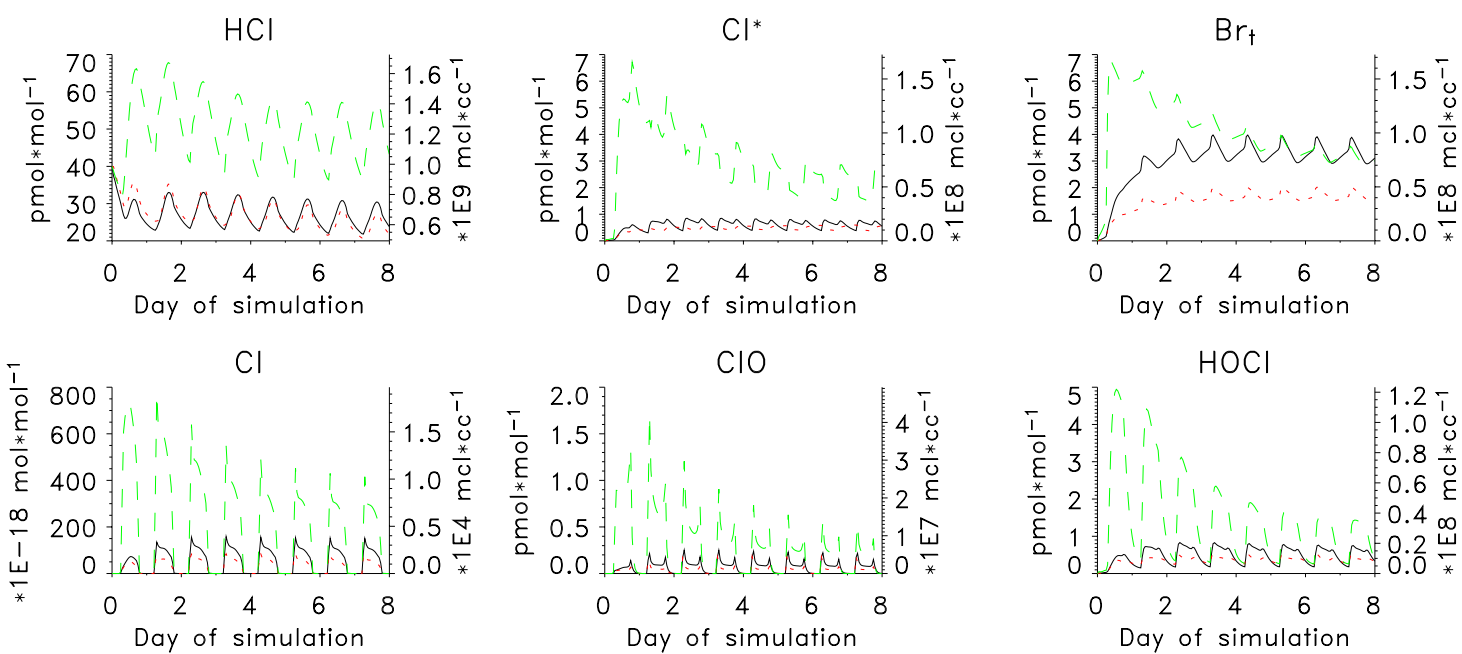

$\mathrm{ClO}$

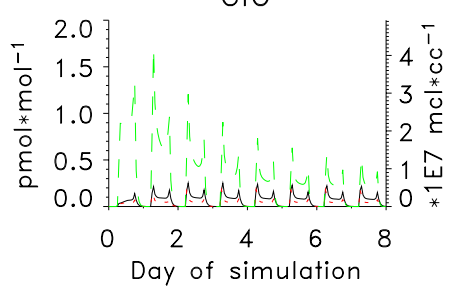

$\mathrm{HOCl}$

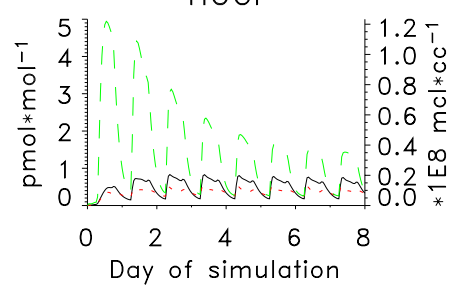

$\mathrm{Cl}_{2}$
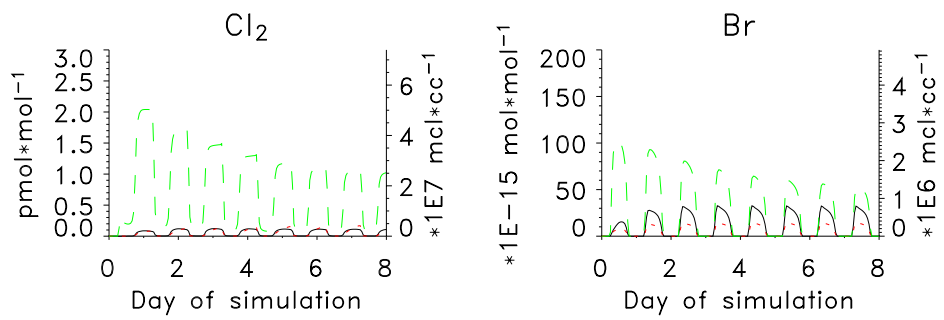

$\mathrm{BrO}$

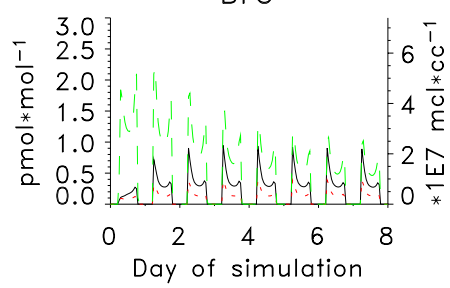

$\mathrm{HOBr}$

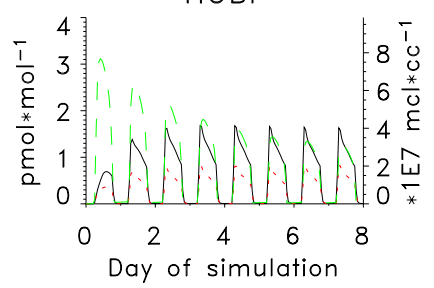

$\mathrm{Br}_{2}$
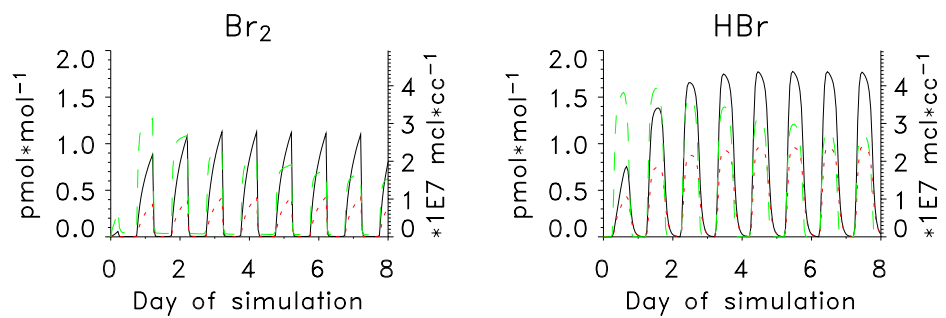

$\mathrm{BrCl}$
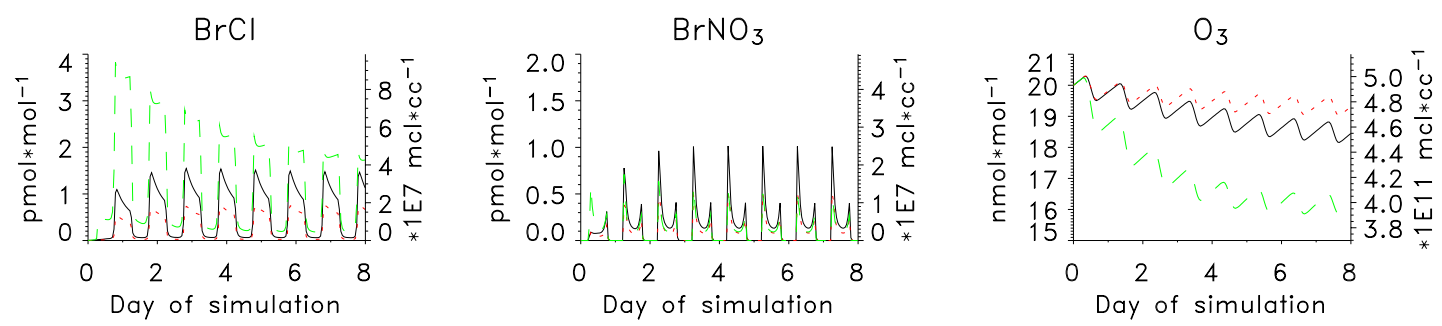

Fig. 5. Simulated mixing ratios of some halogen species and ozone in the gas phase in model runs M1 (black), M2 (red), and M3 (green).

for small particles because they absorb acids faster and because the ocean-atmosphere exchange process that introduces fresh, undersaturated sea-salt particles is slower. Acting in opposition to the absorption of acids is the halogen activation mechanism described by (R1) and (R2), which consumes acidity. Since the halogen cycling is more intensive in small particles, their supersaturation successively decreases relative to the larger particles and they even become undersaturated.

\subsection{Halogen cycling}

Measured mixing ratios of $\mathrm{HCl}^{*}$ (primarily $\mathrm{HCl}$ ) averaged $100 \mathrm{pmol} \mathrm{mol}^{-1}$ and varied from below detection limit $\left(30 \mathrm{pmol} \mathrm{mol}^{-1}\right)$ to $250 \mathrm{pmol} \mathrm{mol}^{-1}$; those of $\mathrm{Cl}^{*}(\mathrm{Cl}$ radicals, $\mathrm{Cl}_{2}$, and $\mathrm{HOCl}$ ) averaged $6 \mathrm{pmol} \mathrm{mol}^{-1}$ and varied from below detection limit (about $3 \mathrm{pmol} \mathrm{mol}^{-1}$ for most of the experiment) to $38 \mathrm{pmol} \mathrm{mol}^{-1}$ (Fig. 4). The maximum average mixing ratios of $\mathrm{HCl}^{*}$ and $\mathrm{Cl}^{*}$ over 12-hour periods (dayand nighttime) were 199 and $12 \mathrm{pmol} \mathrm{mol}^{-1}$, respectively, and occurred during daytime. Based on all measurements, 
(a)

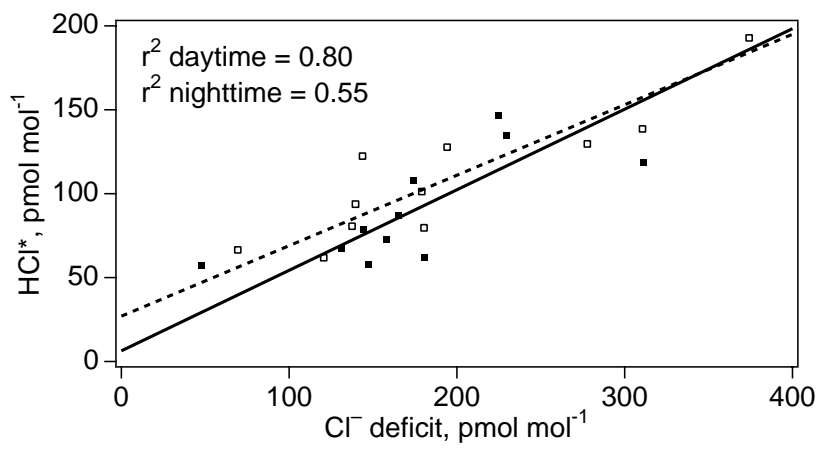

(b)

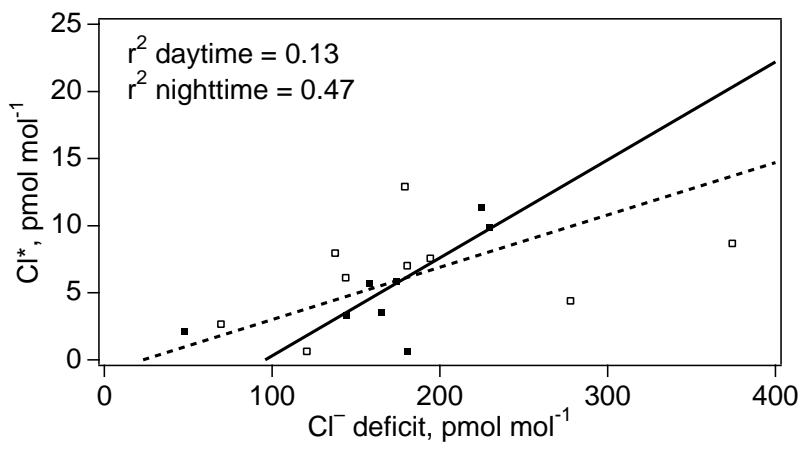

Fig. 6. Mixing ratios of $\mathrm{HCl}^{*}$ (a) and $\mathrm{Cl}^{*}$ (b) averaged over impactor sampling intervals plotted against corresponding measured particulate $\mathrm{Cl}^{-}$deficits summed over all impactor stages (daytime: open squares; nighttime:solid squares). Lines are regressions for daytime (dashed) and nighttime (solid), respectively, calculated by the reduced major axis method (Hirsch and Gilroy, 1984). Regression coefficients: $\mathrm{HCl}^{*}$ vs. $\mathrm{Cl}^{-}$deficit daytime: slope $=0.42$, intercept $=27$; nighttime: slope $=0.48$, intercept $=6.3 ; \mathrm{Cl}^{*}$ vs. $\mathrm{Cl}^{-}$deficit daytime: slope $=0.039$, intercept $=-0.9$; nighttime: slope $=0.073$, intercept $=-7.0$.

mean mixing ratios of both $\mathrm{HCl}^{*}$ and $\mathrm{Cl}^{*}$ were slightly higher during daytime.

The simulated mixing ratios of $\mathrm{HCl}_{\mathrm{g}}$ and $\mathrm{Cl}^{*}$ varied between 20 and $70 \mathrm{pmol} \mathrm{mol}^{-1}$, and 0.5 and $6 \mathrm{pmol} \mathrm{mol}^{-1}$, respectively (Fig. 5), which are near the lower ends of the ranges of the respective measured concentrations. The higher mixing ratios during the latter part of the experiment were associated with the pollution episode and are not representative of the cleaner conditions considered in the simulations. The simulated $\mathrm{HCl}_{\mathrm{g}}$ concentrations increased during the daytime, peaked before dusk, and decreased overnight to minimum values at dawn. Afternoon maxima in measured $\mathrm{HCl}^{*}$ concentrations were observed on some days but a consistent diel pattern was not evident over the course of the experiment.

Simulated $\mathrm{ClO}, \mathrm{HOCl}$ and $\mathrm{Cl}$ peaked during daytime while simulated $\mathrm{Cl}_{2}$ peaked at night. The net effect is relatively little diel variability in simulated $\mathrm{Cl}^{*}$ (Fig. 5). Absolute concentrations of simulated $\mathrm{Cl}^{*}$ and associated diel patterns also differed among the cases studied. Simulation M1 indicated lower nighttime concentrations and an early morning minimum whereas simulation M3 indicated a nighttime maximum.

In the following discussion, particulate halogen "excesses" and "deficits" refer to absolute departure from sea water composition (i.e. nmol or $\mathrm{pmol} \mathrm{m}^{-3}$ ) while the terms "enrichment" and "depletion" refer to relative deviations. The measured particulate $\mathrm{Cl}^{-}$deficits summed over all impactor stages do not show any clear diel variability (Fig. 4). The temporal variability over the course of the campaign resembled that of $\mathrm{HCl}^{*}$ with larger deficits measured towards the end in association with high levels of pollutants. $\mathrm{HCl}^{*}$ mixing ratios were strongly positively correlated to particulate $\mathrm{Cl}^{-}$deficits during daytime and less strongly correlated at night, while correlations of $\mathrm{Cl}^{*}$ mixing ratios to $\mathrm{Cl}^{-}$ deficits were weak or insignificant (Fig. 6).

The simulated $\mathrm{Cl}^{-}$enrichments $(\mathrm{EFCl}=$ $\left.\left(\mathrm{Cl}^{-} / \mathrm{Mg}^{2+}\right)_{\text {sample }} /\left(\mathrm{Cl}^{-} / \mathrm{Mg}^{2+}\right)_{\text {seawater }}\right)$ in sea-salt particles were between 0.95 and 0.80 , indicating $\mathrm{Cl}^{-}$depletions similar to observed values. The $\mathrm{Cl}^{-}$enrichment of sub- $\mu \mathrm{m}$ particles was between 0.75 and 0.25 , indicating less $\mathrm{Cl}^{-}$ depletion than was observed; median measured enrichments were 0.35 and essentially zero for the 0.65 and $0.33 \mu \mathrm{m}$ fractions, respectively (Table 3 ). This difference can be explained partly by the fact that the simulated sea-salt particles were externally mixed with sulphate particles at initialisation and did not physically mix during the model runs. They were therefore less acidic than actual sub- $\mu \mathrm{m}$ particles. The simulated diel pattern of the total (summed over all aerosol size fractions) $\mathrm{Cl}^{-}$deficit showed a maximum rate of increase during afternoon and minimum at night (Fig. 7), which is consistent with diel variability indicated by the measurements (Fig. 4).

Mixing ratios of total gaseous inorganic $\mathrm{Br}\left(\mathrm{Br}_{\mathrm{t}}\right)$ varied from below detection limits (1.5-2 $\left.\mathrm{pmol} \mathrm{mol}^{-1}\right)$ to $9 \mathrm{pmol} \mathrm{mol}^{-1}$ (Fig. 8a) with average mixing ratio $3.7 \mathrm{pmol} \mathrm{mol}^{-1}$. The maximum values were measured during daytime and the mean for mixing ratios during daytime was greater than that for nighttime. Mixing ratios also varied temporally over the course of the experiment in a similar way as $\mathrm{Cl}^{*}$ (compare Fig. 4). The particulate $\mathrm{Br}^{-}$ deficit in bulk samples, expressed as mixing ratios, varied from 1 to $6 \mathrm{pmol} \mathrm{mol}^{-1}$ with average value $3.2 \mathrm{pmol} \mathrm{mol}^{-1}$. Like $\mathrm{Br}_{\mathrm{t}}$, highest individual $\mathrm{Br}^{-}$deficits and a higher mean deficit were measured during the daytime. The nighttime $\mathrm{Br}^{-}$deficit data were positively correlated to $\mathrm{Br}_{\mathrm{t}}$ while the daytime data were not (Fig. 9).

Maximum simulated mixing ratios of $\mathrm{Br}_{\mathrm{t}}$ varied between 1.5 and $7.0 \mathrm{pmol} \mathrm{mol}^{-1}$ (Fig. 5), which are within the range of measured concentrations (Fig. 8). The higher values were associated with the higher concentrations of sea-salt particles in simulation M3. Maximum simulated mixing ratios of individual $\mathrm{Br}$ species $\left(\mathrm{HBr}, \mathrm{HOBr}, \mathrm{BrO}, \mathrm{BrCl}\right.$, and $\mathrm{Br}_{2}$ were 
a)

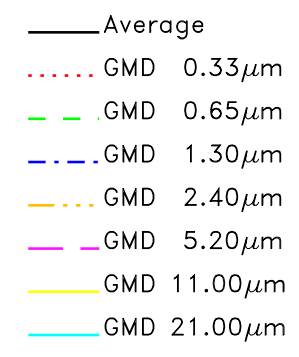

b)
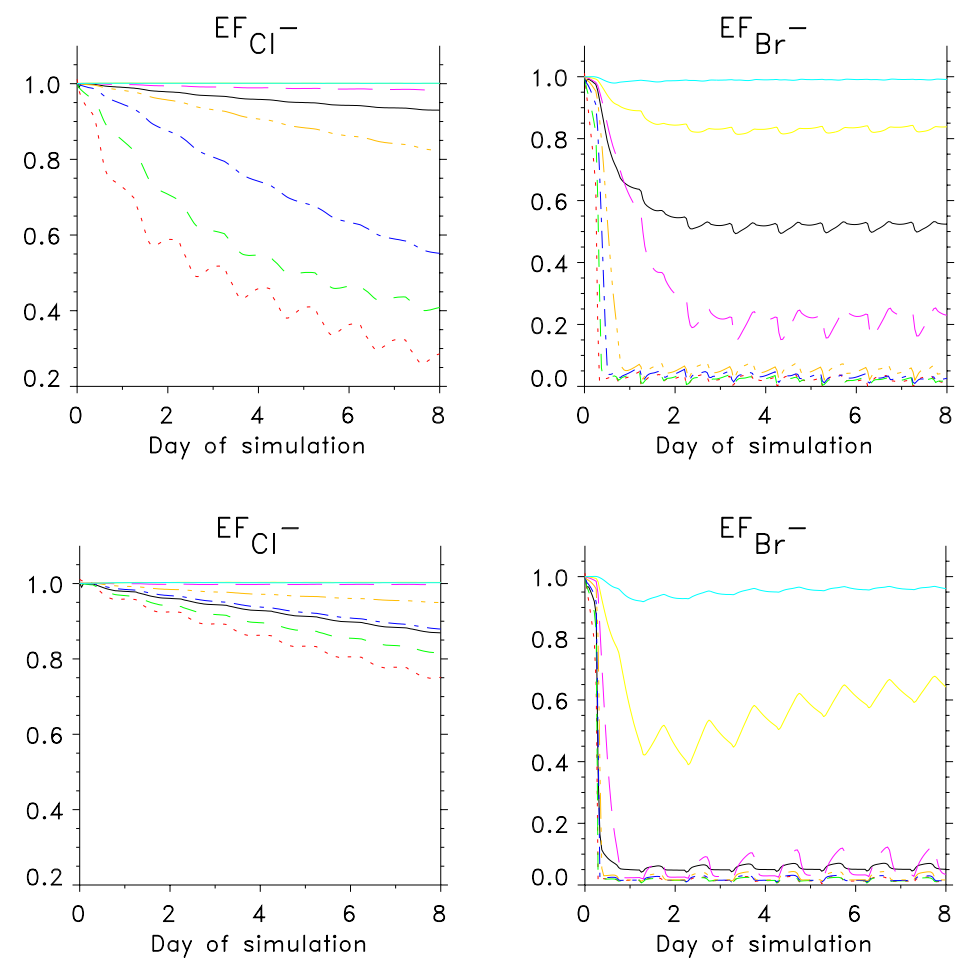

Fig. 7. Simulated concentrations of $\mathrm{Cl}^{-}$and $\mathrm{Br}^{-}$enrichment factors in sea-salt aerosols for model runs $\mathrm{M} 1$ (a) and $\mathrm{M} 3$ (b).

each in the range of a few (1.5 to 3.0) $\mathrm{pmol} \mathrm{mol}^{-1}$; $\mathrm{HBr}$, $\mathrm{HOBr}$ and $\mathrm{BrO}$ peaked during daytime and $\mathrm{BrCl}$ and $\mathrm{Br}_{2}$ peaked at night. In all cases, $\mathrm{Br}_{\mathrm{t}}$ mixing ratios were highest in the early morning and lowest at dusk. In simulations $\mathrm{M} 1$ and $\mathrm{M} 2$ the $\mathrm{Br}_{\mathrm{t}}$ mixing ratio increased slowly overnight whereas, in simulation $\mathrm{M} 3$, the $\mathrm{Br}_{\mathrm{t}}$ mixing ratio increased quickly after dusk. These differences account for higher average daytime mixing ratios of $\mathrm{Br}_{\mathrm{t}}$ in simulations $\mathrm{M} 1$ and M2 compared to higher average nighttime mixing ratios in simulation M3. The diurnal variabilities of $\mathrm{Br}_{\mathrm{t}}$ in the model are thus quite in agreement with measurements, with higher daytime $\mathrm{Br}_{\mathrm{t}}$ mixing ratio on average but with some occasions when daytime mixing ratios were lower than those during the following night. Von Glasow et al. (2003) investigated the diurnal variability of $\mathrm{Br}_{\mathrm{t}}$ with the 1-dimensional model MISTRA and found that presence of clouds influenced diurnal variability of $\mathrm{Br}_{\mathrm{t}}$. In simulations with clouds, $\mathrm{Br}_{2}$ and $\mathrm{BrCl}$, which would otherwise accumulate in the gas phase, dissolved into the cloud droplets causing nighttime minima in mixing ratios of these two compounds.

Diurnal variability in $\mathrm{Br}^{-}$and $\mathrm{EFBr}$ also differed between simulations $\mathrm{M} 1$ and $\mathrm{M} 2$ relative to $\mathrm{M} 3$. Under the conditions of less intensive halogen cycling, the bromine volatilisation took place only during daytime when there were significant concentrations of $\mathrm{HOBr}$ driving the $\mathrm{Br}$ activation reaction $\mathrm{R} 1$. In simulation M2 no volatilisation took place at night and the EFBr increased due to the continuous air-sea exchange in the model replacing the bromine-depleted sea-salt particles with fresh ones. In simulations M1 and M3 with more intensive halogen cycling, larger gas phase mixing ratios of $\mathrm{BrCl}$ and $\mathrm{Cl}_{2}$ developed after dusk and bromine volatilisation occurred as $\mathrm{BrCl}$ and $\mathrm{Cl}_{2}$ dissolved into the sea-salt aerosol, volatilising $\mathrm{Br}_{2}$. In $\mathrm{M} 3$ with slower air-sea exchange this nighttime volatilisation led to the lower nighttime mixing ratios of $\mathrm{Br}^{-}$(and decreased $\mathrm{EFBr}$ ) compared to daytime. In M1 with faster air-sea exchange the nighttime volatilisation was smaller than the relative increase of $\mathrm{Br}^{-}$due to air-sea exchange, and the diurnal pattern was similar to that of simulation M2. Differences between diurnal variabilities in M1 and M3 can be seen in Fig. 7. The model results can be compared to the measured $\mathrm{Br}^{-}$deficits (Fig. 8b) with slightly larger deficits during daytime than at night on average. Von Glasow and Crutzen (2003) recently compared diurnal cycles of $\mathrm{Br}^{-}$in 1-D MISTRA model simulations with intensive and less intensive bromine volatilisation. They obtained opposite diurnal cycles in agreement with our simulations, however with much larger amplitude in a low $\mathrm{Br}^{-}$volatilisation case. Rancher and Kritz (1980) reported diurnal variabilities of $\mathrm{Br}_{\mathrm{t}}$ and $\mathrm{Br}^{-}$over the equatorial Atlantic Ocean with consistently higher $\mathrm{Br}_{\mathrm{t}}$ and lower $\mathrm{Br}^{-}$during daytime.

Measured mixing ratios of $\mathrm{BrO}$ were less than detection limits of $\approx 2 \mathrm{pmol} \mathrm{mol}^{-1}$ throughout the experiment, which is consistent with model predictions (Fig. 5). To examine if a diel cycle in $\mathrm{BrO}$ can be discerned, data for changes in $\mathrm{BrO}$ mixing ratios over 3-hour periods, which generally have smaller uncertainties as noted above, were plotted over 
(a)

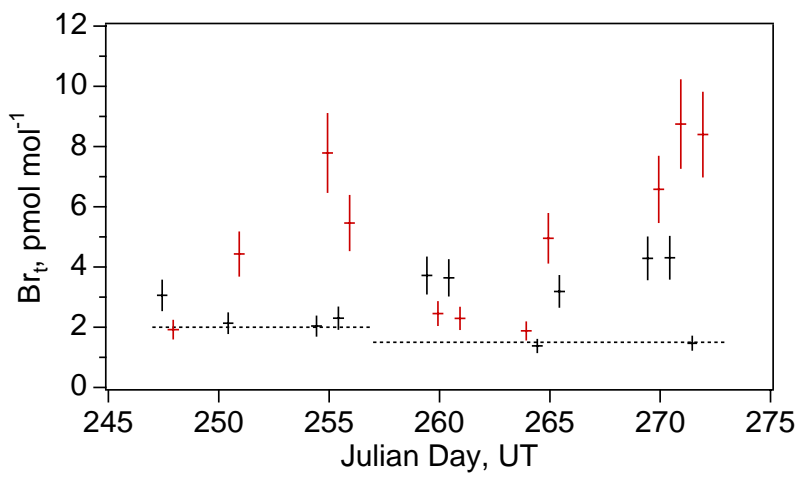

(b)

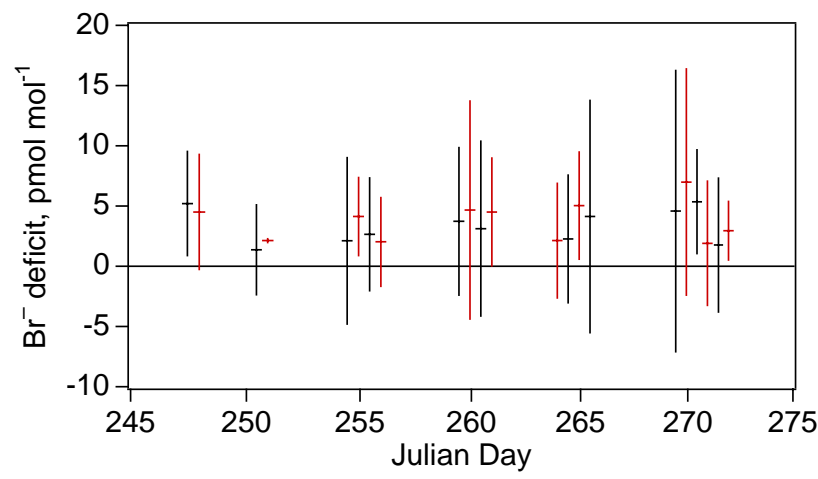

Fig. 8. Measured mixing ratios of (a) $\mathrm{Br}_{\mathrm{t}}$ and (b) corresponding $\mathrm{Br}^{-}$deficits in bulk aerosol during daytime (red) and nighttime (black); detection limits for $\mathrm{Br}_{\mathrm{t}}$ are indicated with horizontal dashed lines in panel a. The widths of the red and black dash symbols correspond to the sampling intervals. Vertical error bars correspond to precisions stated in the text.

local time of the day (end of the 3-hour period) (Fig. 10). All data were lower than their respective detection limits, which reached as little as $0.5 \mathrm{pmol} \mathrm{mol}^{-1}$ when visibility was excellent. Only data with detection limits lower than 2 pmol mol ${ }^{-1}$ were considered. The data scattered around zero, however, changes in $\mathrm{BrO}$ mixing ratio during the 3-hour period ending at 11:00 local time were mostly negative, averaging $-0.3 \mathrm{pmol} \mathrm{mol}^{-1}$, which would be consistent with decreasing $\mathrm{BrO}$ mixing ratios during morning as simulated by MOCCA (Fig. 5). Evaluated BrO mixing ratios lower than the detection limit have to be taken with great care, as they may result from systematic features in the DOAS spectra, caused by diurnal changes of the lamp emission structures or by changes in trace gases absorbing in the wavelength region covered by the spectrum. Nonetheless, plots of changes of other trace gas concentrations as measured by DOAS do not show any noticeable diurnal variations, indicating that the uncertainty of the evaluation is mostly caused by random noise in the spectra.

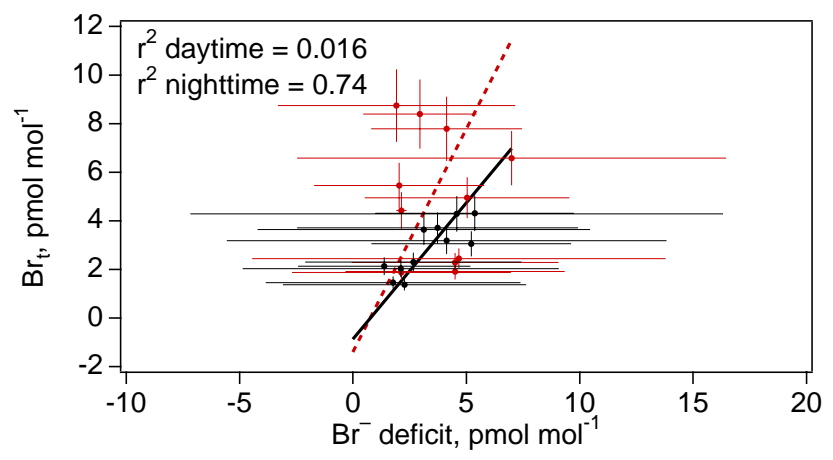

Fig. 9. Measured mixing ratios of $\mathrm{Br}_{\mathrm{t}}$ versus corresponding $\mathrm{Br}^{-}$ deficits in bulk aerosol during the daytime (red) and nighttime (black). Error bars correspond to precisions stated in the text. Slanted lines are regressions for daytime (red dashed) and nighttime (black solid), respectively, calculated by the reduced major axis method (Hirsch and Gilroy, 1984). Regression parameters are as follows: $\mathrm{Br}_{\mathrm{t}} \mathrm{vs}$. $\mathrm{Br}^{-}$deficit daytime: slope $=1.84$, intercept $=-1.40$; $\mathrm{Br}_{\mathrm{t}}$ vs. $\mathrm{Br}^{-}$deficit nighttime: slope $=1.12$, intercept $=-0.86$.

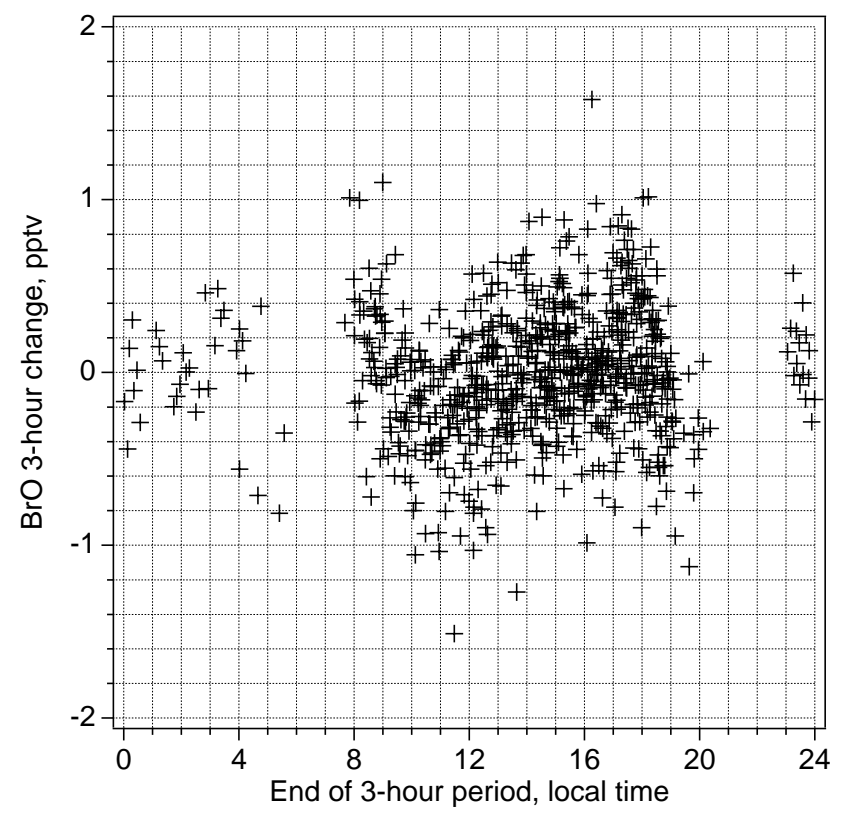

Fig. 10. Changes in $\mathrm{BrO}$ mixing ratios over a nominal 3-hour period plotted versus local time of end of the 3-hour period. Actual time differences between the two spectra used varied between 2.5 and 3.5 hours. All values were lower than their respective detection limits.

The measured $\mathrm{Br}^{-}$concentrations and enrichments relative to sea salt indicate that most of the super- $\mu \mathrm{m}$ size fractions were depleted in $\mathrm{Br}^{-}$(Table 3, Fig. 11). Bromide depletion increased with decreasing diameter from an average EF of about 0.5 for the $>21 \mu \mathrm{m}$ size fraction to 0.09 for the $2.4 \mu \mathrm{m}$ size fraction. The $2.4 \mu \mathrm{m}$ and $1.3 \mu \mathrm{m}$ size fractions of most samples were almost completely depleted in $\mathrm{Br}^{-}$. The smallest size fractions were typically enriched in $\mathrm{Br}^{-}$ relative to sea-salt ( $\mathrm{EFBr}>1$ for most of the samples). 
(a)

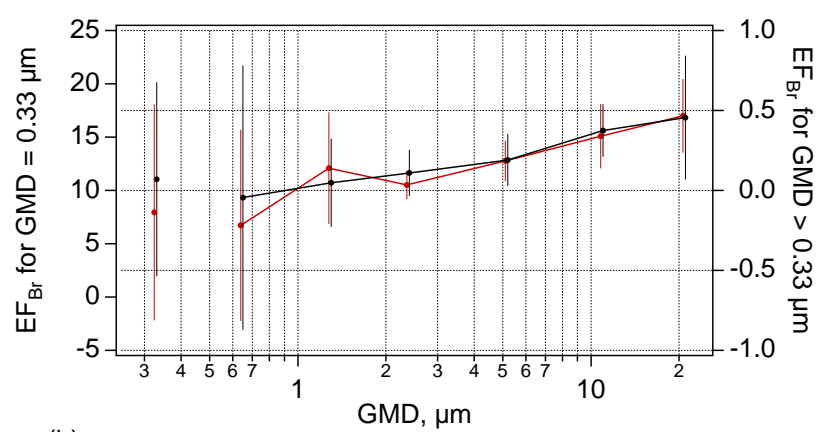

(b)

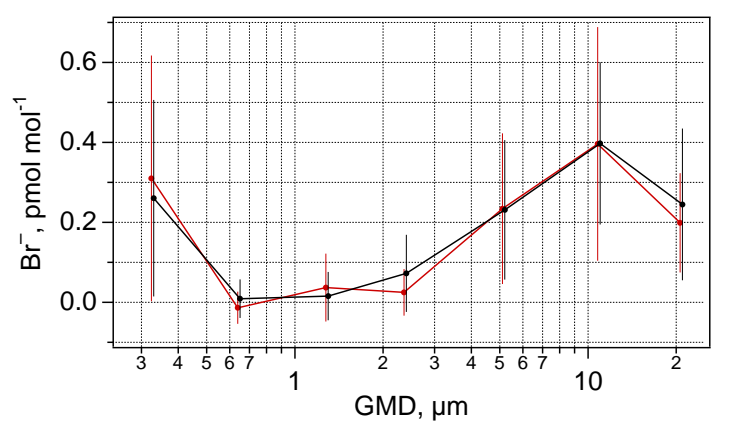

Fig. 11. Average particulate $\mathrm{Br}^{-}$enrichment factors (a) and mixing ratios (b) as a function of size based on measured concentrations during daytime (red) and nighttime (black). Error bars are \pm 1 standard deviation of the eleven values from which the averages were calculated for each point plotted. Daytime values are slightly offset horizontally to reduce overlap. Note the different scale for $\mathrm{EFBr}$ for the $0.33 \mu \mathrm{m}$ size fraction in panel a.

The measured and simulated $\mathrm{Br}^{-}$enrichments were comparable for most size fractions. Simulated enrichments integrated over all size fractions were between 0.6 and 0.9 and decreased from $\approx 0.95$ in the largest particles to $\approx 0.05$ in the $2.4 \mu \mathrm{m}$ size bin (Figs. 7 and 11). However, the measured excess of $\mathrm{Br}^{-}$in smallest size fraction (GMD $0.33 \mu \mathrm{m}$, Table 3) was not reproduced by the model. The simulated sub$\mu \mathrm{m}$ sea-salt particles lost their bromine almost entirely. Externally mixed sulphate particles accumulated some bromine but this gain was at most 20 times less than the corresponding loss from similarly sized sea-salt particles.

Most of the measured particle mass in the sub- $\mu \mathrm{m}$ size fraction is contributed by $\mathrm{SO}_{4}^{2-}, \mathrm{NH}_{4}^{+}$and associated $\mathrm{H}_{2} \mathrm{O}$ (e.g. Table 2). These fine particles are also enriched in potassium and sometimes calcium relative to sea-salt, presumably due to terrestrial or combustion sources of $\mathrm{K}$ and $\mathrm{Ca}$. Most sub- $\mu \mathrm{m}$ aerosols (or their surface layers) in the Hawaiian MBL are presumably hydrated and acidic so any associated $\mathrm{Br}^{-}$should recycle, which makes it difficult to explain the enrichment by inorganic $\mathrm{Br}$ of non-marine origin. One possibility is that the $\mathrm{Br}^{-}$is associated with chemically distinct particles, e.g. particles originating from combustion of leaded fuel in East-Asian vehicle fleets or particles origi- nating from biomass burning. The highest $\mathrm{Br}^{-}$enrichments were observed in association with the presence of significant pollutants, which trajectories suggest may have been transported from Asia. Alternatively, MOCCA may be missing some important process that leads to accumulation of sub$\mu \mathrm{m} \mathrm{Br}{ }^{-}$. See Sander et al. (2003) for further discussion of inorganic bromine chemistry in the MBL.

\subsection{Interactions among halogens, ozone and nitrogen com- pounds}

Sensitivity of the model to $\mathrm{O}_{3}$ mixing ratio was explored. When the initial mixing ratio of $\mathrm{O}_{3}$ was increased from 20 (simulation M1) to $30 \mathrm{nmol} \mathrm{mol}^{-1}$ (simulation M4), mixing ratios of reactive halogen species in the gas phase also increased (Fig. 12). Bromide depletions of sea-salt particles increased by up to $8 \%$. Observed $\mathrm{O}_{3}$ variations between 15 and $35 \mathrm{nmol} \mathrm{mol}^{-1}$ during the campaign may thus explain some of the variability in the measured halogen species. Gasphase inorganic halogens reduce $\mathrm{O}_{3}$ concentrations, making the sea-salt aerosol a catalytic reactor for $\mathrm{O}_{3}$ destruction. This effect can be seen by comparing $\mathrm{O}_{3}$ in simulations M2 and $\mathrm{M} 3$ (see Fig. 5). The $\mathrm{O}_{3}$ mixing ratio at the end of simulation M3 with high sea-salt is $16 \mathrm{nmol} \mathrm{mol}^{-1}$ while in M2, with the lowest sea-salt mixing ratio, the $\mathrm{O}_{3}$ mixing ratio is $19 \mathrm{nmol} \mathrm{mol}^{-1}$. The $\approx 25 \%$ increase in sea-salt mixing ratio corresponds to a $16 \% \mathrm{O}_{3}$ decrease.

The role of the sea-salt particles in $\mathrm{O}_{3}$ chemistry is rather complex. Ozone is destroyed catalytically by $\mathrm{Br}$ via reactions (R3) to (R5) and to some extent by the analogous Cl reactions. Reactions (R4) and (R5) convert $\mathrm{HO}_{2}$ to $\mathrm{OH}$, which also leads to $\mathrm{O}_{3}$ destruction via the $\mathrm{HO}_{\mathrm{x}}$ cycle:

$\mathrm{OH}+\mathrm{O}_{3} \rightarrow \mathrm{HO}_{2}+\mathrm{O}_{2}$

$\mathrm{HO}_{2}+\mathrm{O}_{3} \rightarrow \mathrm{OH}+2 \mathrm{O}_{2}$

These $\mathrm{O}_{3}$ losses are partly offset by formation through reactions with $\mathrm{NO}$

$\mathrm{XO}+\mathrm{NO} \rightarrow \mathrm{X}+\mathrm{NO}_{2} \quad(\mathrm{X}=\mathrm{OH}, \mathrm{Br}, \mathrm{Cl})$

followed by $\mathrm{NO}_{2}$ photolysis

$\mathrm{NO}_{2}+\mathrm{h} v \rightarrow \mathrm{NO}+\mathrm{O}$.

Ozone losses by various pathways were calculated in simulations M1 and M3 to quantify the effect of halogens on MBL $\mathrm{O}_{3}$ concentration. In Fig. 13, the diel variation of $\mathrm{O}_{3}$ loss due to (R3) plus its $\mathrm{Cl}$ analog is compared to losses due to $\mathrm{O}_{3}$ photolysis and the $\mathrm{HO}_{\mathrm{x}}$ and $\mathrm{NO}_{\mathrm{x}}$ cycles. The contribution from (R8) was not subtracted from that of (R3) and was plotted separately because this reaction simultaneously contributes to $\mathrm{O}_{3}$ formation in the $\mathrm{NO}_{\mathrm{x}}$ cycle. Photolysis is the most important $\mathrm{O}_{3}$ sink with a magnitude of approximately $1500 \mathrm{pmol} \mathrm{O}_{3} \mathrm{~mol}^{-1} \mathrm{day}^{-1}$. In MOCCA this sink is approximately compensated by the stratospheric contribution. Figure 13 shows that the halogens deplete $\mathrm{O}_{3}$ in the 

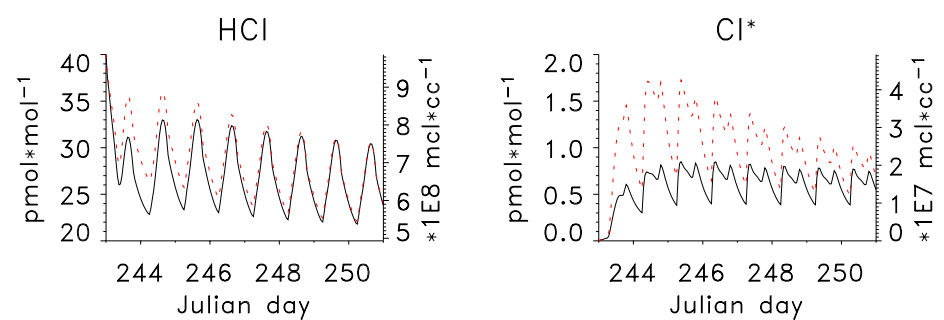

$\mathrm{Cl}$

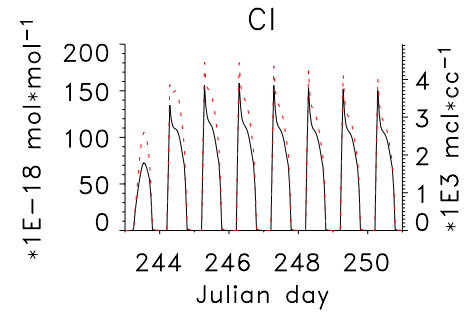

$\mathrm{Cl}_{2}$

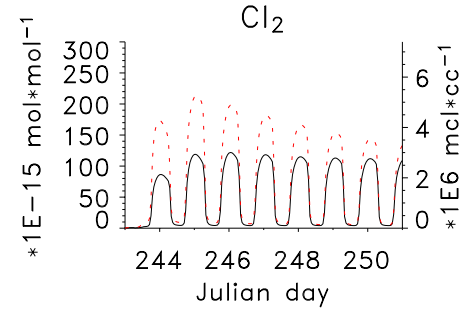

$\mathrm{HOBr}$

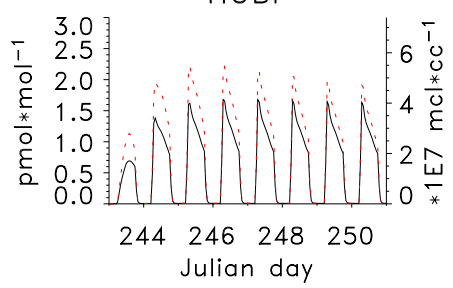

$\mathrm{BrCl}$

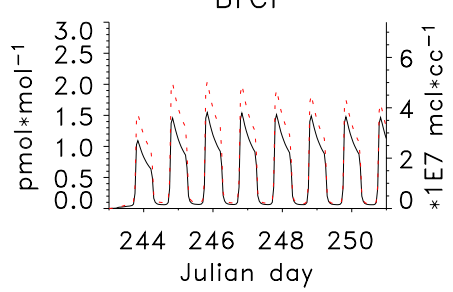

$\mathrm{ClO}$

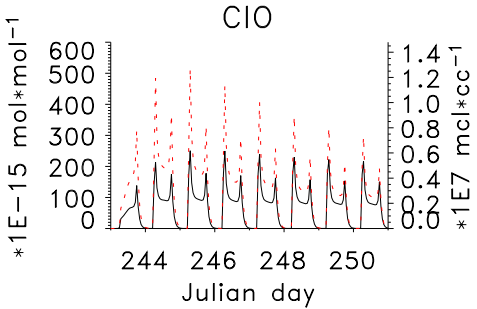

$\mathrm{Br}$

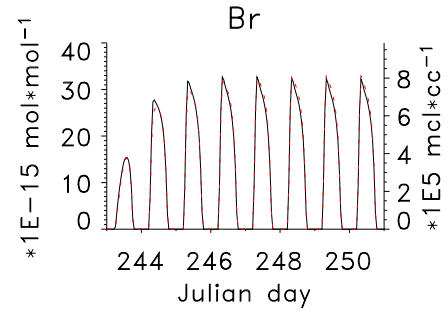

$\mathrm{Br}_{2}$

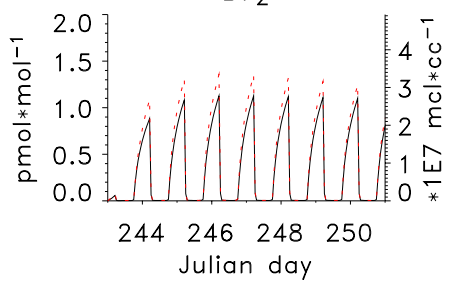

$\mathrm{BrNO}_{3}$

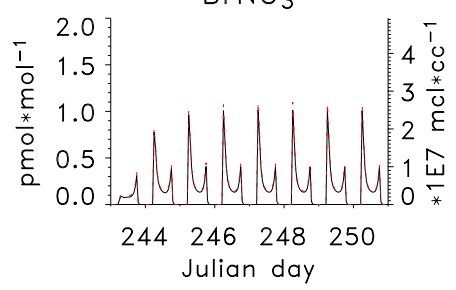

$\mathrm{Br}_{+}$

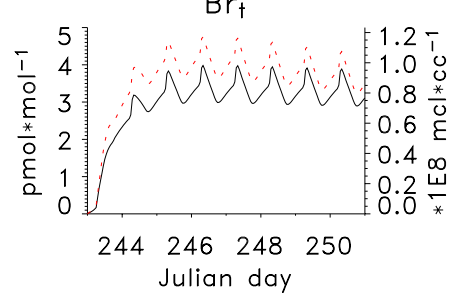

$\mathrm{HOCl}$

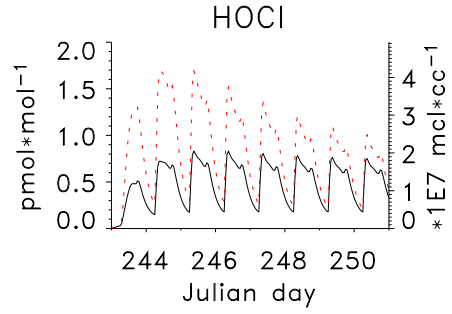

$\mathrm{BrO}$

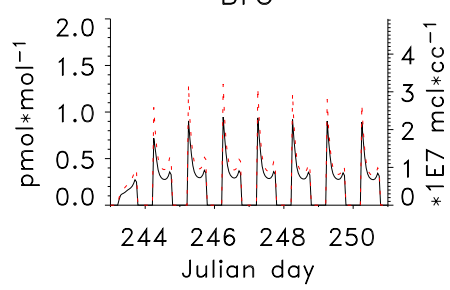

$\mathrm{HBr}$

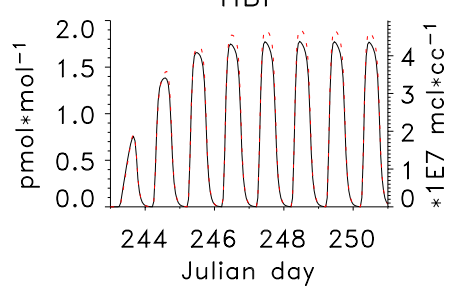

$\mathrm{O}_{3}$

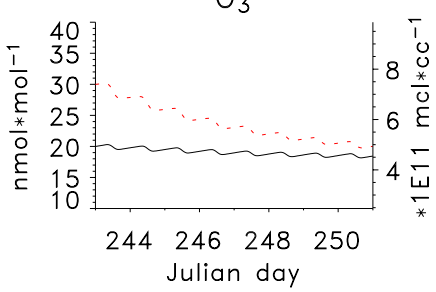

Fig. 12. Simulated mixing ratios of some halogen species and ozone in the gas phase in model runs M1 (black) and M4 (red, dotted).

MBL to an extent similar to that of the $\mathrm{HO}_{\mathrm{x}}$ cycle $(200$ to $\left.700 \mathrm{pmol} \mathrm{mol}^{-1} \mathrm{day}^{-1}\right)$. Increasing sea-salt aerosol concentration (and particle surface area) from that in simulation M1 to that in $\mathrm{M} 3$, increases $\mathrm{O}_{3}$ depletion by approximately a factor of two. Dry deposition of $\mathrm{O}_{3}$ to the sea surface was of similar magnitude to that of the $\mathrm{HO}_{\mathrm{x}}$-cycle sink in both simulations. At the same time, photochemical $\mathrm{O}_{3}$ formation decreased by a factor of 2 from 1540 to $790 \mathrm{pmol} \mathrm{mol}^{-1}$ day $^{-1}$ at the beginning of simulation M3. This decrease was caused by more intensive removal of $\mathrm{NO}_{\mathrm{x}}$ from the gas phase, which was mainly caused by heterogeneous reaction of $\mathrm{BrNO}_{3}$ with sea-salt particles. It is the coupling between $\mathrm{NO}_{\mathrm{x}}$ and halogen cycles that makes the sea-salt $-\mathrm{O}_{3}$ interaction complex. Halogen nitrates are formed through

$\mathrm{XO}+\mathrm{NO}_{2} \rightarrow \mathrm{XNO}_{3}(\mathrm{X}=\mathrm{Br}, \mathrm{Cl})$.

In the model these nitrates react with liquid aerosols (Sander et al., 1999):

$$
\begin{aligned}
& \mathrm{XNO}_{3}+\mathrm{H}_{2} \mathrm{O}_{(1)} \rightarrow \mathrm{HOX}+\mathrm{HNO}_{3} \\
& \mathrm{XNO}_{3}+\mathrm{X}^{-} \rightarrow \mathrm{X}_{2}+\mathrm{NO}_{3}^{-} .
\end{aligned}
$$




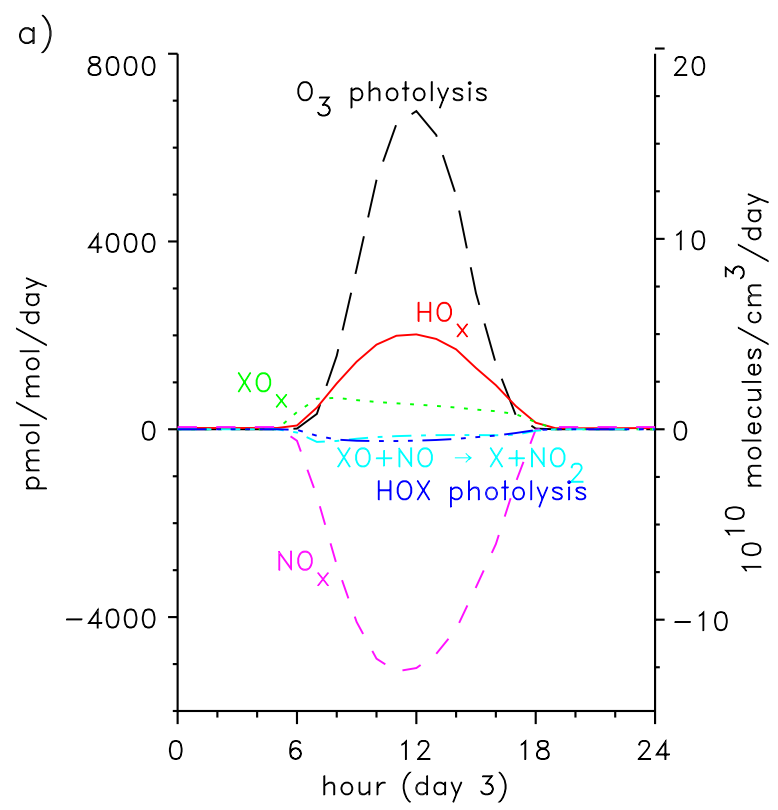

a)
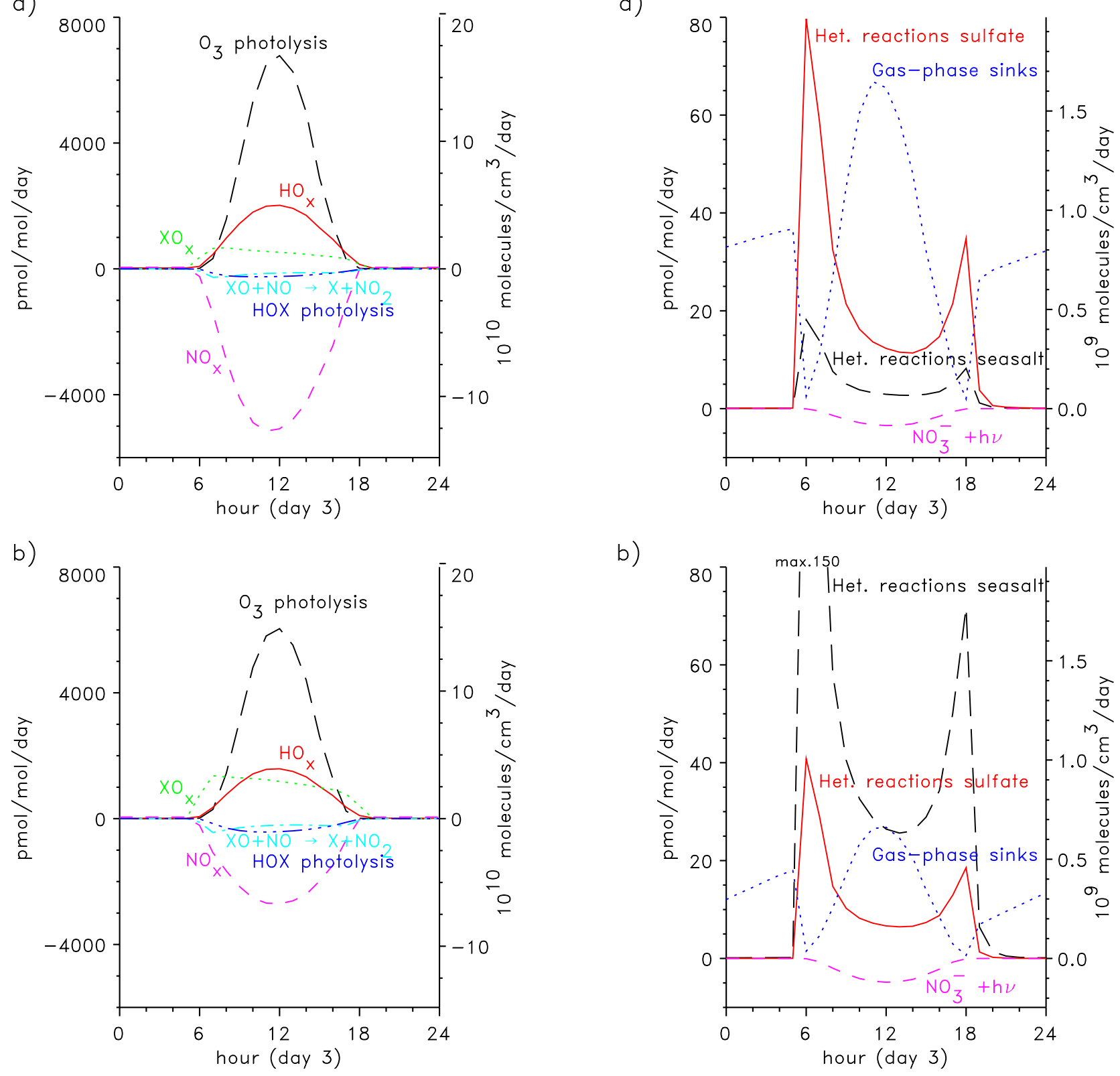

b)

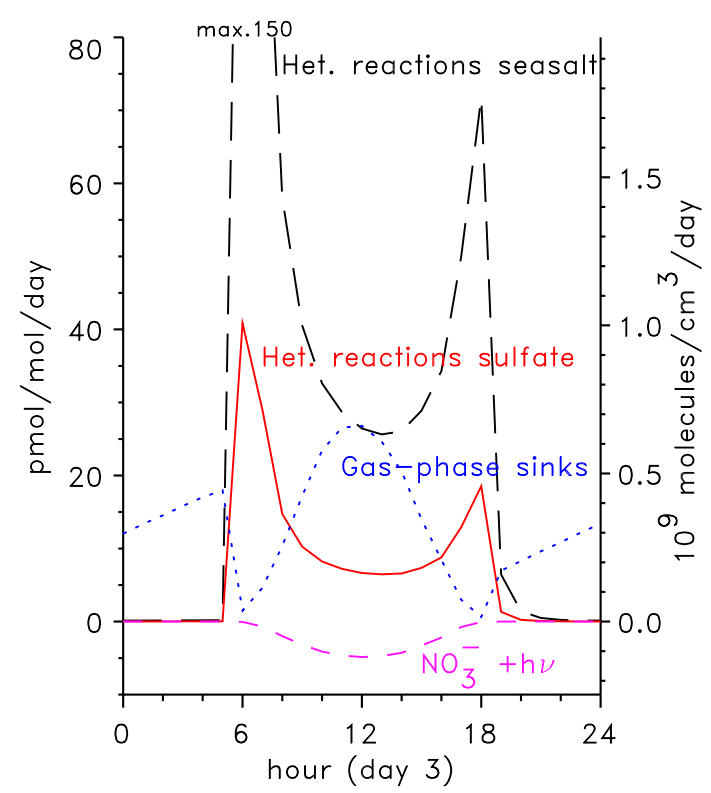

Fig. 13. Diel cycles of different ozone sinks from simulations M1 (a) and M3 (b). Negative values imply net ozone production.

Nitric acid can be reduced to $\mathrm{NO}_{2}$ in the gas phase by photolysis and by reaction with $\mathrm{OH}$. In the aqueous phase, $\mathrm{NO}_{3}^{-}$ can be photolysed to $\mathrm{NO}_{2}$ and $\mathrm{OH}$.

The budgets of different $\mathrm{NO}_{\mathrm{x}}$ sinks are compared in Fig. 14. The gas-phase sinks were mainly reaction of $\mathrm{NO}_{2}$ with $\mathrm{OH}(55$ to $60 \%)$ and reaction of DMS with $\mathrm{NO}_{3}$. Gas-phase reduction of $\mathrm{HNO}_{3}$ to $\mathrm{NO}_{2}$ was unimportant in both model simulations $\left(0.2 \mathrm{pmol} \mathrm{mol}^{-1} \mathrm{day}^{-1}\right.$ in maxi-

mum). The heterogeneous sink of $\mathrm{NO}_{2}$ (R10) was followed by (R11) or (R12) with $\mathrm{BrNO}_{3}$ responsible for 80 to $95 \%$ of the integrated 24-hour loss of $\mathrm{NO}_{\mathrm{x}}$ through (R10) to (R12). On sea-salt particles the most important heterogeneous reaction of $\mathrm{BrNO}_{3}$ was reaction with $\mathrm{Cl}^{-}$while on the sulphate particles it was hydration. In sea-salt particles a few pmol mol $^{-1}$ day $^{-1}$ of $\mathrm{NO}_{3}^{-}$were reduced back to $\mathrm{NO}_{2}$ through photolysis. This reaction was negligible in sulphate particles. (a) and M3 (b). Negative values are sources from $\mathrm{NO}_{3}^{-}$photolytic reduction in sea-salt particles. 
In Fig. 14 it is shown that in M1 (low sea-salt) the gas-phase reactions were the most important sink of $\mathrm{NO}_{\mathrm{x}}$, although heterogeneous reactions with sulphate particles were responsible for approximately $25 \%$ of the total loss of $\mathrm{NO}_{\mathrm{x}}$. The sulphate particles did not retain the $\mathrm{NO}_{3}^{-}$formed in (R11) and (R12). $\mathrm{HCl}$ scavenged to the particles provided $\mathrm{Cl}^{-}$ to (R12) to form $\mathrm{BrCl}$ and the associated acidity repartitioned the $\mathrm{HNO}_{3}$ to the gas phase. In this way the sulphate particles in the model were effective both in removing $\mathrm{NO}_{\mathrm{x}}$ and re-activating chlorine. In contrast, the seasalt particles in the model retained the $\mathrm{NO}_{3}^{-}$formed through (R11) and (R12). After three days of simulation the mixing ratio of $\mathrm{NO}_{3}^{-}$in aerosol particles reached approximately $100 \mathrm{pmol} \mathrm{mol}^{-1}$, which is rather close to the mean measured mixing ratio (e.g. Table 3). In simulation M1 the heterogeneous sink of $\mathrm{NO}_{\mathrm{x}}$ on sea-salt particles was approximately $5 \%$ of the total. In simulation M3 with higher sea-salt concentration (but the same nss sulphate concentration) the importance of reactions of $\mathrm{BrNO}_{3}$ with sea-salt particles as a sink for $\mathrm{NO}_{\mathrm{x}}$ increased greatly and became the most important, accounting for as much as $60 \%$ of the removal. The photolytic reduction of $\mathrm{NO}_{3}^{-}$in sea-salt particles increased by about $1.4 \mathrm{pmol} \mathrm{mol}^{-1} \mathrm{day}^{-1}$ as a result of these reactions, thereby reducing the net magnitude of this sink by 0.5 to $2.5 \%$.

The accommodation coefficient of $\mathrm{BrNO}_{3}$ is rather uncertain. To test the sensitivity of the model in this regard the sticking coefficient of $\mathrm{BrNO}_{3}$ was decreased from 0.8 (used in simulations M1 to M4) to 0.1 and 0.01 . The effects on oxides of nitrogen were approximately +2 and $+5 \mathrm{pmol} \mathrm{mol}^{-1}$, respectively, and on inorganic volatile bromine 0 and $-1 \mathrm{pmol} \mathrm{mol}^{-1}$, respectively. Comparison of the high- and low-sticking coefficient simulations indicates that the additional oxides of nitrogen were to a large extent missing from the sea-salt particles' nitrate pool, illustrating the complexity of cycling of species through these particles.

It was not possible to directly estimate from the model the response of $\mathrm{O}_{3}$ to the removal of $\mathrm{NO}_{\mathrm{x}}$ through heterogeneous reactions of $\mathrm{BrNO}_{3}$ and $\mathrm{ClNO}_{3}$. However, the difference in $\mathrm{O}_{3}$ formation between $\mathrm{M} 1$ and $\mathrm{M} 3$ was 700 to $900 \mathrm{pmol} \mathrm{mol}^{-1} \mathrm{day}^{-1}$ during the initial day of simulation while the catalytic $\mathrm{O}_{3}$ destruction by the $\mathrm{Br}-\mathrm{BrO}$ and $\mathrm{Cl}-\mathrm{ClO}$ cycles increased by 300 to $600 \mathrm{pmol} \mathrm{mol}^{-1} \mathrm{day}^{-1}$. The total $\mathrm{O}_{3}$ response was -1.0 to $-1.5 \mathrm{nmol} \mathrm{mol}^{-1}$ day $^{-1}$, a range similar to the total $\mathrm{O}_{3}$ sink by photolysis in both simulations.

\section{Conclusions}

A multiphase suite of inorganic $\mathrm{Cl}$ and $\mathrm{Br}$ species and related chemical and physical parameters was measured in the relatively clean easterly trade-wind regime over the North Pacific Ocean at Hawaii during September 1999. Aerosols were sampled over 11 diel cycles with cascade impactors and bulk filters, which were analysed for ionic composition. Volatile inorganic $\mathrm{Cl}$ gases were sampled with tandem mist chambers to segregate $\mathrm{HCl}^{*}$ (primarily $\mathrm{HCl}$ ) and $\mathrm{Cl}^{*}$ (including $\mathrm{Cl}_{2}$ and $\mathrm{HOCl}$ ) fractions. $\mathrm{BrO}, \mathrm{NO}_{2}$ and $\mathrm{O}_{3}$ were measured with a long-path DOAS. Total gaseous inorganic $\mathrm{Br}$ was sampled with alkaline-impregnated filters.

Aerosol $\mathrm{pH}$ as a function of particle size was inferred from the measured phase partitioning and thermodynamic properties of $\mathrm{HCl}$. The photochemical box model MOCCA was parameterized based on observations and the measured concentrations and calculated results were compared with simulations over a representative range of conditions.

Aerosol pHs inferred from measured phase partitioning were acidic for all aerosol size fractions, with those for super$\mu \mathrm{m}$ ranging from the 4.5 to 5.4 (median 5.1). The sub- $\mu \mathrm{m}$ fraction (GMD $0.65 \mu \mathrm{m}$ ) acidities were higher (median $\mathrm{pH}$ 4.6) and more variable. Inferred daytime $\mathrm{pHs}$ tended to be slightly lower than those at night, although daytime median values did not differ statistically from nighttime medians. $\mathrm{pHs}$ predicted by MOCCA were generally in agreement with those inferred from thermodynamic relationships: 4.9 to 5.5 for super- $\mu \mathrm{m}$ fractions and 5.3 to 5.5 for sub- $\mu \mathrm{m}$ fractions. These differences are probably due to the simulations representing a relatively clean subset of the conditions sampled and, for the largest particles, due to the rapid turnover rates and relatively larger infusions of sea-salt alkalinity associated with fresh aerosols. The simulation-based $\mathrm{pHs}$ should therefore be considered upper limits.

Measured mixing ratios of $\mathrm{HCl}^{*}$ ranged from $<30$ to $250 \mathrm{pmol} \mathrm{mol}^{-1}$ and those for $\mathrm{Cl}^{*}$ from $<6$ to $38 \mathrm{pmol} \mathrm{mol}^{-1}$. Afternoon $\mathrm{HCl}^{*}$ maxima were observed on some days but not on others. A consistent diel variation pattern for $\mathrm{HCl}^{*}$ or $\mathrm{Cl}^{*}$ was not observed. Simulated $\mathrm{HCl}$ and $\mathrm{Cl}^{*}\left(\mathrm{Cl}+\mathrm{ClO}+\mathrm{HOCl}+\mathrm{Cl}_{2}\right)$ mixing ratios ranged between 20 and $70 \mathrm{pmol} \mathrm{mol}^{-1}$ and 0.5 and $6 \mathrm{pmol} \mathrm{mol}^{-1}$, respectively, both of which were within the ranges of measured values. While individual components of $\mathrm{Cl}^{*}$ varied diurnally in the simulations, their sum did not, consistent with the lack of a diel cycle in observed $\mathrm{Cl}^{*}$. Simulated $\mathrm{HCl}$ did vary diurnally, peaking before dusk and reaching a minimum at dawn, in agreement with $\mathrm{HCl}^{*}$ observations on some days but not on others.

Mixing ratios of alkaline-reactive $\mathrm{Br}$ varied from $<1.5$ to $9 \mathrm{pmol} \mathrm{mol}^{-1}$ with values tending to be higher during daytime. Particulate Br deficits varied from 1 to $6 \mathrm{pmol} \mathrm{mol}^{-1}$ with the greatest deficits also tending to occur during daytime. Simulated $\mathrm{Br}_{\mathrm{t}}$ and $\mathrm{Br}^{-}$mixing ratios and $\mathrm{EFBr}$ values were similar to those observed with early morning maxima and dusk minima. However, the diel cycles differed in detail among the various simulations. In low-salt simulations halogen cycling was less intense, $\mathrm{Br}^{-}$accumulated and $\mathrm{Br}_{\mathrm{t}}$ and $\mathrm{EFBr}$ increased slowly overnight. In highersalt simulations with more intense halogen cycling $\mathrm{Br}^{-}$ and $\mathrm{EFBr}$ decreased and $\mathrm{Br}_{\mathrm{t}}$ increased rapidly after dusk. Cloud processing, which is not considered in this version of MOCCA, may also affect these diel cycles (von Glasow 
and Crutzen, 2003). Measured $\mathrm{BrO}$ was never above detection limit $\left(\approx 2 \mathrm{pmol} \mathrm{mol}^{-1}\right)$ during the experiment, however relative changes in the $\mathrm{BrO}$ signal during the 3-hour period ending at 11:00 local time were mostly negative, averaging $-0.3 \mathrm{pmol} \mathrm{mol}^{-1}$. Both of these results are consistent with MOCCA simulations of $\mathrm{BrO}$ mixing ratios.

The impact of multiphase halogen cycling on $\mathrm{O}_{3}$ was explored by initialising the MOCCA model with different $\mathrm{O}_{3}$ mixing ratios and sea-salt aerosol concentrations within the ranges of observed values. Increasing sea-salt mixing ratio by $\approx 25 \%$ led to a decrease in $\mathrm{O}_{3}$ of $\approx 16 \%$. The chemistry leading to this decrease is complex and is tied to $\mathrm{NO}_{\mathrm{x}}$ removal by heterogeneous reactions of $\mathrm{BrNO}_{3}$ and $\mathrm{ClNO}_{3}$. The sink of $\mathrm{O}_{3}$ due to the catalytic $\mathrm{X}-\mathrm{XO}$ cycles is estimated at -1.0 to $-1.5 \mathrm{nmol} \mathrm{mol}^{-1} \mathrm{day}^{-1}$, a range similar to that due to $\mathrm{O}_{3}$ photolysis in the MOCCA simulations.

Acknowledgements. We thank C. Adams-Phillips, S. Howell and B. Huebert of the University of Hawaii for use of the tower facility and operational support during the field campaign at Bellows Air Force Station. G. Kleiman assisted in calculating trajectories at MIT. Funding for this work was provided by the German BMBF's program AFO 2000, the U.S. National Science Foundation through award ATM-0003865 to UVA, and the U.S. National Oceanic and Atmospheric Administration through contract NA87RJ0445 to MIT via the Cooperative Institute for Climate and Ocean Research at the Woods Hole Oceanographic Institution.

\section{References}

Ayers, G. P., Gillett, R. W., Cainey, J. M., and Dick, A. L.: Chloride and bromide loss from sea-salt particles in the southern ocean air, J. Atmos. Chem., 33, 299-319, 1999.

Bardwell, C. A., Maben, J. R., Hurt, J. A., Keene, W. C., Galloway, J. N., Boatman, J. F., and Wellman, D.: A technique using highflow, dichotomous filter packs for measuring major atmospheric chemical constituents, Global Biogeochem. Cycles, 4, 151-163, 1990.

Bass, A. M. and Paur, R. J.: The ultraviolet cross-sections of ozone, Proceedings of the Quadrennial Ozone Symposium, Greece (edited by Zerefos, C. and Ghazi, A.), $606617,1984$.

Brauers, T., Hausmann, M., Brandenburger, U., and Dorn, H.-P.: Improvement of differential optical absorption spectroscopy with a multichannel scanning technique, Appl. Opt., 34, 4472-4479, 1995.

Brimblecombe, P. and Clegg, S. L.: Erratum, J. Atmos. Chem., 8, 95, 1989.

Chameides, W. L. and Stelson, A. W.: Aqueous-phase chemical processes in deliquescent sea salt aerosols: A mechanism that couples the atmospheric cycles of S and sea salt, J. Geophys. Res., 97, 20 565-20 580, 1992.

Cicerone, R. J.: Halogens in the troposphere, Rev. Geophys., 19, 123-139, 1981.

Clegg, S. L. and Whitfeldt, M.: Activity coefficients in natural waters, in Pitzer, K. S., Activity Coefficients in Electrolyte Solutions, CRC Press, Boca Raton, FL, 279-434, 1991.

Dickerson, R. R., Rhodes, K. P., Carsey, T. P., Oltmans, S. J., Burrows, J. P., and Crutzen, P. J.: Ozone in the remote marine bound- ary layer: A possible role for halogens, J. Geophys. Res., 104, 21385-21395, 1999.

Draxler, R. R.: HYbrid Single-Particle Lagrangian Integrated Trajectories (HY-SPLIT): Version 3.0-User's guide and model description, NOAA Tech. Memo. ERL/ARL-80, 40, 1995.

Erickson III, D. J., Seuzaret, C., Keene, W. C., and Gong, S.L.: A general circulation model based calculation of $\mathrm{HCl}$ and $\mathrm{ClNO}_{2}$ production from sea salt dechlorination: Reactive Chlorine Emissions Inventory, J. Geophys. Res., 104, 8347-8372, 1999.

Galbally, I. E., Bentley, S. T., and Meyer, C. P.: Mid-latitude marine boundary-layer ozone destruction at visible sunrise observed at Cape Grim, Tasmania, Geophys. Res. Lett., 27, 3841-3844, 2000.

Gerber, H. E.: Relative-humidity parameterization of the Navy aerosol model (NAM), NRL Rep. 8956, Naval Res. Lab., Washington, D. C., 1985.

Gong, S. L., Barrie, L. A., and Blanchet, J.-P.: Modeling sea-salt aerosols in the atmosphere: 1. Model Development, J. Geophys. Res., 102, 3805-3818, 1997.

Graedel, T. E. and Keene, W. C.: The tropospheric budget of reactive chlorine, Global Biogeochem. Cycles, 9, 47-78, 1995.

Harder, J. W., Brault, J. W., Johnston, P. V., and Mount, G. H.: Temperature dependent $\mathrm{NO}_{2}$ cross sections at high spectral resolution, J. Geophys. Res., 102, 3861-3879, 1997.

Hebestreit, R. M., Stutz, J., Rosen, D., Matveev, V., Luria, M., and Platt, U.: DOAS measurements of tropospheric bromine oxide in mid-latitudes, Science, 283, 55-57, 1999.

Hirsch, R. M. and Gilroy, E. J.: Methods of fitting a straight line to data: Examples in water resources, Water. Resour. Bull., 20, 5, 705-711, 1984.

Hönninger, G.: Referenzspektren reaktiver Halogenverbindungen für DOAS-Messungen, Diplomarbeit, Ruprecht-Karls-Universität Heidelberg, Germany, http: //www.iup.uni-heidelberg.de/urmel/abstracts/tit2hg.html, 1999.

Jobson, B. T., Niki, H., Yokouchi, Y., Bottenheim, J., Hopper, F., and Leaitch, R.: Measurements of $\mathrm{C}_{2}-\mathrm{C}_{6}$ hydrocarbons during the Polar Sunrise 1992 Experiment: Evidence for $\mathrm{Cl}$ atom and Br atom chemistry, J. Geophys. Res., 99, 25 355-25 368, 1994.

Jobson B. T., Parrish, D. D., Goldan, P., Kuster, W., Fehsenfeld, F. C., Blake, D. R., Blake, N. J., and Niki, H.: Spatial and temporal variability of nonmethane hydrocarbon mixing ratios and their relation to photochemical lifetime, J. Geophys. Res., 103, 13 557-13 567, 1998.

Keene, W. C. and Savoie, D. L.: The pH of deliquesced sea-salt aerosol in polluted marine air. Geophys. Res. Lett., 25, 21812184, 1998.

Keene, W. C. and Savoie, D. L.: Correction to "The pH of deliquesced sea-salt aerosol in polluted marine air", Geophys. Res. Lett., 26, 1315-1316, 1999.

Keene, W. C., Pszenny, A. A. P., Galloway, J. N., and Hawley, M. E.: Sea-salt corrections and interpretation of constituent ratios in marine precipitation, J. Geophys. Res., 91, 6647-6658, 1986.

Keene, W. C., Talbot, R. W., Andreae, M. O., Beecher, K., Berresheim, H., Castro, M., Farmer, J. C., Galloway, J. N., Hoffman, M. R., Li, .S.-M., Maben, J. R., Munger, J. W., Norton, R. B., Pszenny, A. A. P., Puxbaum, H., Westberg, H., and Winiwarter, W.: An intercomparison of measurement systems for vapor- and particulate-phase concentrations of formic and acetic 
acids, J. Geophys. Res., 94, 6457-6471, 1989.

Keene, W. C., Pszenny, A. A. P., Jacob, D. J., Duce, R. A., Galloway, J. N., Schultz-Tokos, J. J., Sievering, H., and Boatman, J. F.: The geochemical cycling of reactive chlorine through the marine troposphere, Global Biogeochem. Cycles, 4, 407-430, 1990.

Keene, W. C., Maben, J. R., Pszenny, A. A. P., and Galloway, J. N.: Measurement technique for inorganic chlorine gases in the marine boundary layer, Environ. Sci. Technol., 27, 866-874, 1993.

Keene, W. C., Sander, R., Pszenny, A. A. P., Vogt, R., Crutzen, P. J., and Galloway, J. N.: Aerosol pH in the marine boundary layer: A review and model evaluation, J. Aerosol Sci., 29, 339-356, 1998.

Keene, W. C., Pszenny, A. A. P., Maben, J. R., and Sander, R.: Variation of marine aerosol acidity with particle size, Geophys. Res. Lett., 29, 7, 10.1029/2001GL013881, 2002.

Laskin, A., Gaspar, D. J., Wang, W., Sherri, W., Hunt, S. W., Cowin, J. P., Colson, S. D., and Finlayson-Pitts, B. J.: Reactions at interfaces as a source of sulfate formation in sea salt particles, Science, 301, 340-344, 2003.

Laszlo, B., Kurylo, M. J., and Huie, R. E.: Absorption cross sections, kinetics of formation, and self-reaction of the IO radical produced via laser photolysis of $\mathrm{N}_{2} \mathrm{O} / \mathrm{I}_{2} / \mathrm{N}_{2}$ mixtures, J. Phys. Chem., 99, 11 701-11 707, 1995.

Leser, H., Hönninger, G., and Platt, U.: MAX-DOAS measurements of $\mathrm{BrO}$ and $\mathrm{NO}_{2}$ in the marine boundary layer, Geophys. Res. Lett., 30, 10, 10.1029/2002GL015811, 2003.

Li, S. M., Yokouchi, Y., Barrie, L. A., Muthuramu, K., Shepson, P. B., Bottenheim, J. W., Sturges, W. T., and Landsberger, S.: Organic and inorganic bromine compounds and their composition in the Arctic troposphere during polar sunrise, J. Geophys. Res., 99, 25 415-25 428, 1994.

Maben, J. R., Keene, W. C., Pszenny, A. A. P., and Galloway, J. N.: Volatile inorganic chlorine in surface air over eastern North America, Geophys. Res. Lett., 22, 3513-3516, 1995.

Marsh, A. R. W. and McElroy, W. J.: The dissociation constant and Henry's law constant of $\mathrm{HCl}$ in aqueous solution, Atmos. Environ., 19, 1075-1080, 1985.

Martinez, M., Arnold, T., and Perner, D.: The role of bromine and chlorine chemistry for arctic ozone depletion events in $\mathrm{Ny}$ Ålesund and comparison with model calculations, Ann. Geophys., 17, 941-956, 1999.

Martinez, M., Perner, D., Hackenthal, E.-M., Külzer, S., and Schütz, L.: Measurements of $\mathrm{NO}_{3}$ at Helgoland during the NORDEX campaign in October 1996, J. Geophys. Res., 105, 22 685-22 695, 2000.

McFiggans, G., Allan, B., Coe, H., Plane, J. M. C., Carpenter, L. J., and O'Dowd, C.: A modeling study of iodine chemistry in the marine boundary layer, J. Geophys. Res., 105, 14371-14385, 2000.

Meng, Z. and Seinfeld, J. H.: Time scales to achieve atmospheric gas-aerosol equilibrium for volatile species, Atmos. Environ., 30, 2889-2900, 1996.

Mozurkewich, M.: Mechanisms for the release of halogens from sea-salt particles by free radical reactions, J. Geophys. Res., 100, 14 199-14 207, 1995.

O’Dowd, C. D., Jimenez, J. L., Bahreini, R., Flagan, R. C., Seinfeld, J. H., Hameri, K., Pirjola, L., Kulmala, M., Jennings, S. G., and Hoffmann, T.: Marine aerosol formation from biogenic iodine emissions, Nature, 417, 632-636, 2002.

Parrish, D. D., Hahn, C. J., Williams, E. J., Norton, R. B., Fehsen- feld, F. C., Singh, H. B., Shetter, J. D., Gandrud, B. W., and Ridley, B. A.: Reply to comment on "Indications of photochemical histories of Pacific air masses from measurements of atmospheric trace gases at Pt. Arena, California”, J. Geophys, Res., 98, 14 995-14 997, 1993.

Pitzer, K. S.: Activity Coefficients in Electrolyte Solutions, CRC Press, Boca Raton, FL, 1991.

Platt, U.: Differential optical absorption spectroscopy (DOAS), In: Air monitoring by spectroscopic techniques, M. W. Sigrist, Ed., Chemical Analysis Series, 127, John Wiley \& Sons, 1994.

Platt, U. and Perner, D.: Measurements of atmospheric trace gases by long path differential UV/visible absorption spectroscopy, Optical and Laser Remote Sensing (edited by D. K. Killinger and A. Mooradien), Springer Ser. Optical Sci., 39, 95-105, 1983.

Pszenny, A. A. P., Castelle, A. J., Galloway, J. N., and Duce, R. A.: A study of the sulfur cycle in the Antarctic marine boundary layer, J. Geophys. Res., 94, 9818-9830, 1989.

Pszenny, A. A. P., Keene, W. C., Jacob, D. J., Fan, S., Maben, J. R., Zetwo, M. P., Springer-Young, M., and Galloway, J. N.: Evidence of inorganic chlorine gases other than hydrogen chloride in marine surface air, Geophys. Res. Lett., 20, 699-702, 1993.

Rancher, J. and Kritz, M. A.: Diurnal fluctuation of Br and I in the marine atmosphere, J. Geophys. Res., 85, 5581-5587, 1980.

Sander, R.: Compilation of Henry's law constants for inorganic and organic species of potential importance in environmental chemistry, version 3, http://www.mpch-mainz.mpg.de $/ \sim_{\text {sander/ }}$ res/henry.html, 1999.

Sander, R. and Crutzen, P. J.: Model study indicating halogen activation and ozone destruction in polluted air masses transported to sea, J. Geophys. Res., 101, 9121-9138, 1996.

Sander, R., Rudich, Y., von Glasow, R., and Crutzen, P. J.: The role of $\mathrm{BrNO}_{3}$ in marine tropospheric chemistry: A model study, Geophys. Res. Lett., 26, 2858-2860, 1999.

Sander, R., Keene, W. C., Pszenny, A. A. P., Arimoto, R., Ayers, G. P., Baboukas, E., Cainey, J. M., Crutzen, P. J., Duce, R. A., Hönninger, G., Huebert, B. J., Maenhaut, W., Mihalopoulos, N., Turekian, V. C., and van Dingenen, R.: Inorganic bromine in the marine boundary layer: A critical review, Atmos. Chem. Phys., 3, 1301-1336, 2003.

Saxena, P., Mueller, P. K., Kim, Y. P., Seinfeld, J. H., and Koutrakis, P.: Coupling thermodynamic theory with measurements to characterize acidity of atmospheric particles, Aerosol Sci. Technol., 19, 279-293, 1993.

Singh, H. B., Gregory, G. L., Anderson, B., Browell, E., Sachse, G. W., Davis, D. D., Crawford, J., Bradshaw, J. D., Talbot, R., Blake, D. R., Thornton, D., Newell, R., and Merrill, J.: Low ozone in the marine boundary layer of the tropical Pacific Ocean: Photochemical loss, chlorine atoms, and entrainment, J. Geophys. Res., 101, 1907-1917, 1996a.

Singh, H. B., Thakur, A. N., and Chen, Y. E.: Tetrachloroethylene as an indicator of low $\mathrm{Cl}$ atom concentrations in the troposphere, Geophys. Res. Lett., 23, 1529-1532, 1996b.

Slinn, S. A. and Slinn, W. G. N.: Predictions for particle deposition on natural waters, Atmos. Environ., 14, 1013-1016, 1980.

Spicer, C. W., Chapman, E. G., Finlayson-Pitts, B. J., Plastridge, R. A., Hubbe, J. M., Fast, J. D., and Berkowitz, C. M.: Observations of molecular chlorine in coastal air, Nature, 394, 355-356, 1998.

Stutz, J. and Platt, U.: Numerical analysis and estimation of the statistical error of differential optical absorption spectroscopy 
measurements with least-squares methods, Appl. Opt., 35, 6041, 1996.

Tanaka, P. L., Oldfield, S., Neece, J. D., Mullins, C. B., and Allen, D. T.: Anthropogenic sources of chlorine and ozone formation in urban atmospheres, Environ. Sci. Technol., 34, 4470-4473, 2000.

Tang, I. N.: Thermodynamic and optical properties of mixedsalt aerosols of atmospheric importance, J. Geophys. Res., 102, 1883-1893, 1997.

Tang, I. N. and Munkelwitz, H. R.: Water activities, densities, and refractive indices of aqueous sulphates and sodium nitrate droplets of atmospheric importance, J. Geophys. Res., 99, 18 801-18 808, 1994.

Vogt, R., Crutzen, P. J., and Sander, R.: A mechanism for halogen release from sea-salt aerosol in the remote marine boundary layer, Nature, 383, 327-330, 1996.

Von Glasow, R. and Crutzen, P. J.: Model study of multiphase DMS oxidation with a focus on halogens, Atmos. Chem. Phys. Discuss., 3, 6733-6777, 2003.

Von Glasow, R., Sander, R., Bott, A., and Crutzen, P. J.: Modeling halogen chemistry in marine boundary layer 2 . Interactions with sulfur and the cloud-covered MBL, J. Geophys. Res., 107, 4323, doi:10.1029/2001JD000943, 2002.
Wagner, T. and Platt, U.: Satellite mapping of enhanced BrO concentration in the troposphere, Nature, 395, 486-490, 1998.

Wahner, A., Ravishankara, A. R., Sander, S. P., and Friedl, R. R.: Absorption cross section of $\mathrm{BrO}$ between 312 and $385 \mathrm{~nm}$ at 298 and 223 K, Chem. Physics Letters, 152, 507-512, 1988.

Wennberg, P. O., Cohen, R. C., Stimpfle, R. M., Koplow, J. P., Anderson, J. G., Salawitch, R. J., Fahey, D. W., Woodbridge, E. L., Keim, E. R., Gao, R. S., Webster, C. R., May, R. D., Toohey, D. W., Avallone, L. M., Proffitt, M. H., Loewenstein, M., Podolske, J. R., Chan, K. R., and Wofsy, S. C.: Removal of stratospheric $\mathrm{O}_{3}$ by radicals: In situ measurements of $\mathrm{OH}, \mathrm{HO}_{2}, \mathrm{NO}, \mathrm{NO}_{2}$, $\mathrm{ClO}$, and $\mathrm{BrO}$, Science, 266, 398-404, 1994.

Wingenter, O. W., Kubo, M. K., Blake, N. J., Smith, Jr., T. W., Blake, D. R., and Rowland, F. S.: Hydrocarbon and halocarbon measurements as photochemical and dynamical indicators of atmospheric hydoxyl, atomic chlorine and vertical mixing obtained during Lagrangian flights, J. Geophys. Res., 101, 4331-4340, 1996.

Zhu, X., Prospero, J. M., Millero, F. J., Savoie, D. L., and Brass, G. W.: The solubility of ferric iron in marine aerosol solutions at ambient relative humidities, Mar. Chem., 38, 91-107, 1992. 